\title{
Flow at the toe of a spillway
}

\author{
I. - THE "OPEN TOE" SPILLWAY \\ BY F. M. HENDERSON, \\ SENIOR LEGTURER IN CWIL ENGINEERING \\ UNIVERSITY OF CANTERBURY, CHRISTCHURCH, NEW ZEALAND
}

(Texte français p. 740.)

\begin{abstract}
The problem, is that of the flow conditions at the toe of a spillway which is mounted over an open tunnel. Solutions are obtained for two cases: 1) The tunnel gate is closed so that the tannel is full, or part full, of stationary water; 2) The tunnel gate is open and water is discharging over the spillway and through the
\end{abstract}

tunnel. Experimental results are in good agreement with theory, subject to certain limitations, which are however usually observed in practice. A second paper will present results for the more usual case in which the spillway toe is a curved solid surface.

\section{1. - INTRODUCTION}

The general problem considered is the deflection of flow from the inclined to the horizontal direction at the toe of a spillway. The pressures and bending moments on the sidewalls are dependent on the distribution of the centripetal pressure developed as the jet changes direction; the problem is complicated however by the fact that the higher pressure on the outer streamlines (i.e. those of larger radius of curvature) gives rise to lower velocities, which in turn cause an appreciable local thickening of the jet, particularly pronounced in bucket spillways where the angle of deflection approaches a right angle.

There are of course other complications in the form of aeration and boundary layer development as the water moves down the face of the spillway. However, allowance can be made for these factors once a solution of the primary problem is obtained: i.e., assuming that the water is inviscid and not aerated, to find the velocity and pressure distributions and the extent to which the jet thickens locally as it passes through the curve.

The two papers introduced here deal with this primary problem; the first with the case in which there is an open sluiceway, or tunnel, at the base of the spillway, and the second with the more usual case in which there is a curved solid surface filling the angle between the sloping spillway face and the horizontal.

The first case arises in those hydroelectric schemes where it is convenient to place the spillway block on the line of the diversion channel, which then forms a tunnel in the lower part of the spillway block. When construction is complete this tunnel may be closed with a concrete plug, or it may be closed only by a gate so that in an emergency it may be used as a dewatering sluiceway. The present paper is concerned with this "open-sluice" case, and with the question of how the open mouth of the tunnel affects the flow of water down the face of the spillway.

Theoretical solutions are obtained for two cases: (a) the tunnel gate is closed, so that water is flowing over the spillway crest only; and $(b)$ the tunnel gate is fully open so that water is flowing over the spillway crest and through the tunnel. In both cases experimental results are presented which are in good agreement with the theory. 


\section{2. - TUNNEL GATE CLOSED}

\section{Theoretical solution.}

The boundary conditions in this case are comparatively simple, as shown in Figure 1.

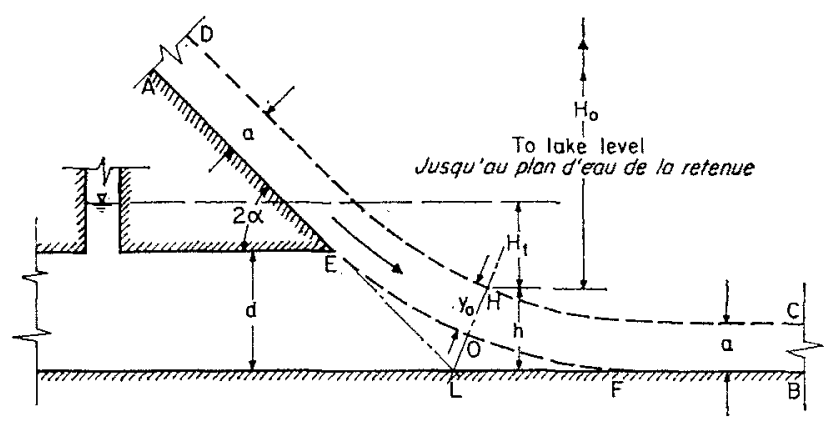

Frg. 1

The closed sluice case. The basic flow situation. Galerie fermée. Schéma d'écoulement.

There are two free boundaries, DHC and EOF, and the water in the tunnel behind EOF is at
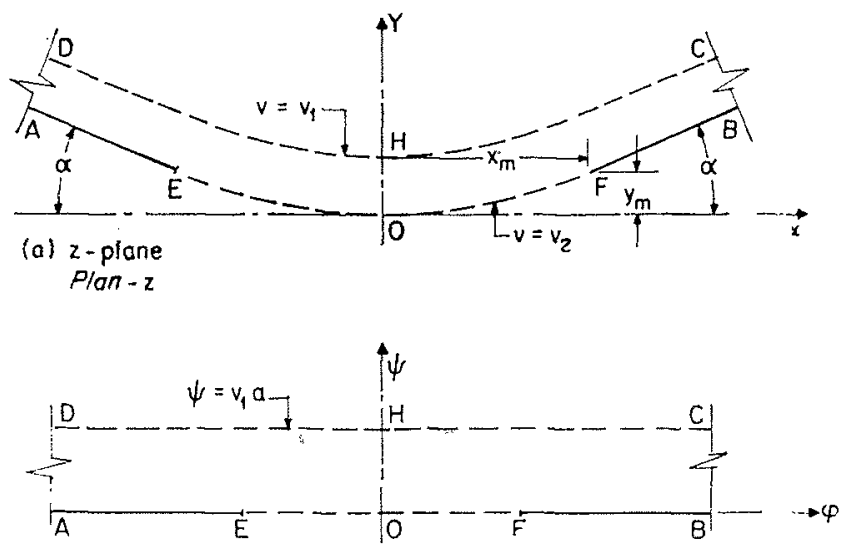

(b) w-plane

Plan-w

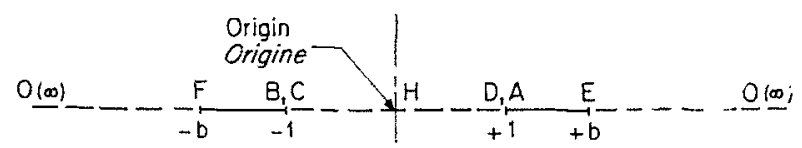

(c) 5 -plane

Plan- $\zeta$

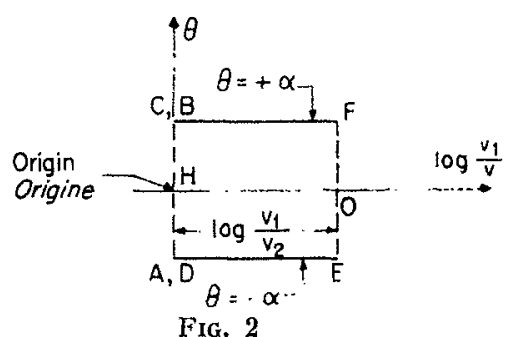

(d) T - plane Plon.T

FIG. 2

The closed sluice case. The mapping problem. Galerie fermée. Problème de représentation. rest. The velocity along $\mathrm{DHC}$ will be constant if we assume that gravity effects are negligibly small, i.e. that changes in the vertical height of the surface DHC in the neighbourhood of the sluice opening are small compared with the velocity head already possessed by the flow, and this assumption will be made in the following analysis. The velocity along EOF will be constant whether we make this assumption or not, since EOF is a line not of constant pressure, but of constant piezometric head equal to that of the still water in the tunnel. The effects of fluid viscosity are ignored.

Before proceeding with the analysis it is convenient to dispose the physical plane, or $z$-plane, as shown in Figure $2(a)$, where, as in Figure 1, free boundaries are shown as dotted lines and solid boundaries as full lines. Following the usual procedure [1] with this class of problem we map three other planes:

-- That of the complex potential $w=0+i \psi$, Figure $2(b)$;

- An intermediate $\zeta$ plane such that the region of flow maps on to the upper half of this plane, Figure 2(c);

- The plane of $\mathrm{T}=\log \mathrm{U} \frac{d z}{d w}=\log \frac{U}{v}+i n$,

Figure $2(d)$,

where $U$ is some standard velocity, usually that on a free streamline, 0 is the angle that the resultant velocity vector makes with the $\mathrm{X}$-axis, and $v$ is the magnitude of the resultant velocity. On this last plane all straight solid boundaries on the $z$-plane, and all free streamlines, map into straight lines.

We choose $U=v_{1}$, the velocity on DHC. Since the field of flow is symmetrical about the line $\mathrm{HO}, \mathrm{O}$ can be placed at the origin of the $z$ and w planes. Let $v_{2}\left(<v_{1}\right)$ be the velocity along EOF, and $2 l$ the length of the curve EOF. Then on the $w$-plane the points $\mathrm{E}$ and $\mathrm{F}$ have abscissae $-v_{2} l$ and $+v_{2} l$ respectively. On the $\zeta$ plane the abscissae of these points are $+b$ and - $b$; the magnitude of $b$ is as yet unknown but will depend on $v_{1}, v_{\varepsilon}, a$, and $l$, where $a$ is the depth of flow at a great distance upstream or downstream. We define o as increasing in the direction of flow, i.e. $v_{x}=+\partial_{\varphi} / \partial x$, etc.

On the $\zeta$ plane the flow situation consists of a source at D, A, and a sink at C, B, the flow on 
the upper half of the plane being equal to $v_{1} a$. Hence the $w-\zeta$ equation is

i.e.

$$
w=\frac{v_{1} a}{\pi} \log \frac{\zeta-1}{\zeta+1}
$$

At the point $\mathrm{E}$,

$$
\zeta=-\operatorname{coth} \frac{\pi w}{2 v_{1} a}
$$

hence:

$$
\zeta=+b, \quad w=-v_{2} l
$$

$$
b=\operatorname{coth} \frac{\pi v_{2} l}{2 v_{1} a}
$$

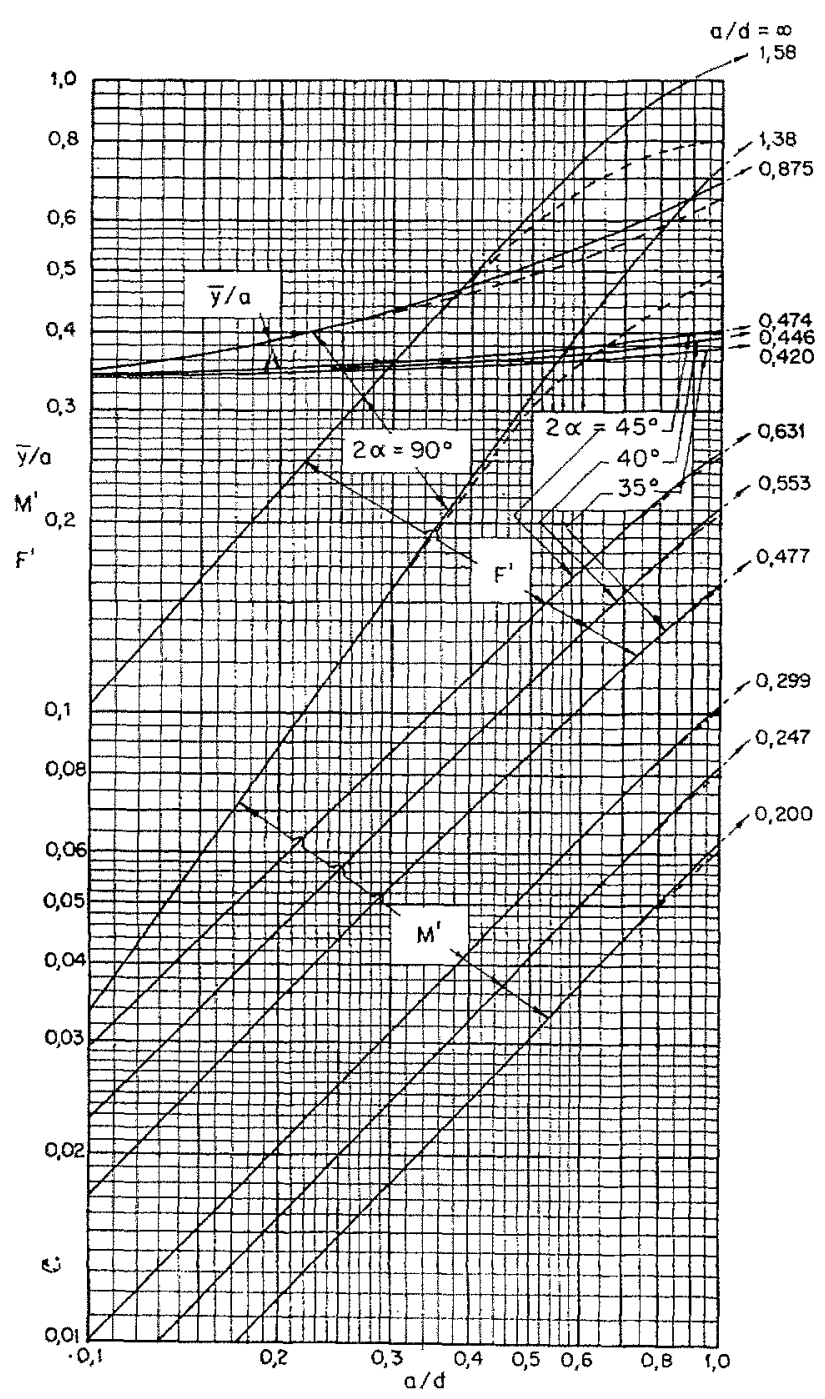

Fig. 3

The closed sluice case.

Variation of the dimensionless ratios $\mathrm{M}^{\prime}, \mathrm{F}^{\prime}$ and $y^{\prime}$ with the ratio $a / d$.

Full lines: complete theory.

Broken lines: free vortex approximation. Galerie fermée.

Variation des coefficients adimensionnels $M^{\prime}, F^{\prime}$ et $\mathrm{y}^{\prime}$ en fonction du rapport a/d.

Les courbes pleines correspondent à la thérie complète; les courbes en pointillé, $\dot{a}$ l'approximation du vortex libre.
On the T-plane, it is clear that the boundaries of the flow map into the boundary of a rectangle of width $\mathrm{BF}=\log \left(v_{1} / v_{2}\right)$ and height $\mathrm{BA}=\mathbf{2} \alpha$. Hence by the Schwarz-Cristoffel transformation:

$$
\begin{aligned}
\mathrm{T} & =\mathrm{G} \int \frac{d \zeta}{\sqrt{\left(\zeta^{2}-1\right)\left(\zeta^{2}-b^{2}\right)}}+\mathrm{L} \\
& =\frac{\mathrm{G}}{b} \mathrm{~F}(1 / b, \zeta)+\mathrm{L}
\end{aligned}
$$

where $F(1 / b, \zeta)$ denotes the elliptic integral of the first kind having a modulus $1 / b$. So as to follow the usual notation for these integrals, we substitute $1 / b=k$. From the boundary conditions at $A$ and $B$ it follows that $\mathrm{L}=0$, $\mathrm{G}=-i \alpha / \mathrm{K} k$, where $\mathrm{K}$ is the complete elliptic integral (with limits 1 and 0 ). Hence from (1) and (3).

$$
\mathrm{T}=\log \frac{v_{1}}{v}+i 0=\frac{i \alpha}{\mathrm{K}} \mathrm{F}\left(k, \operatorname{coth} \frac{\pi_{1} \omega}{2 v_{1} a}\right)(4)
$$

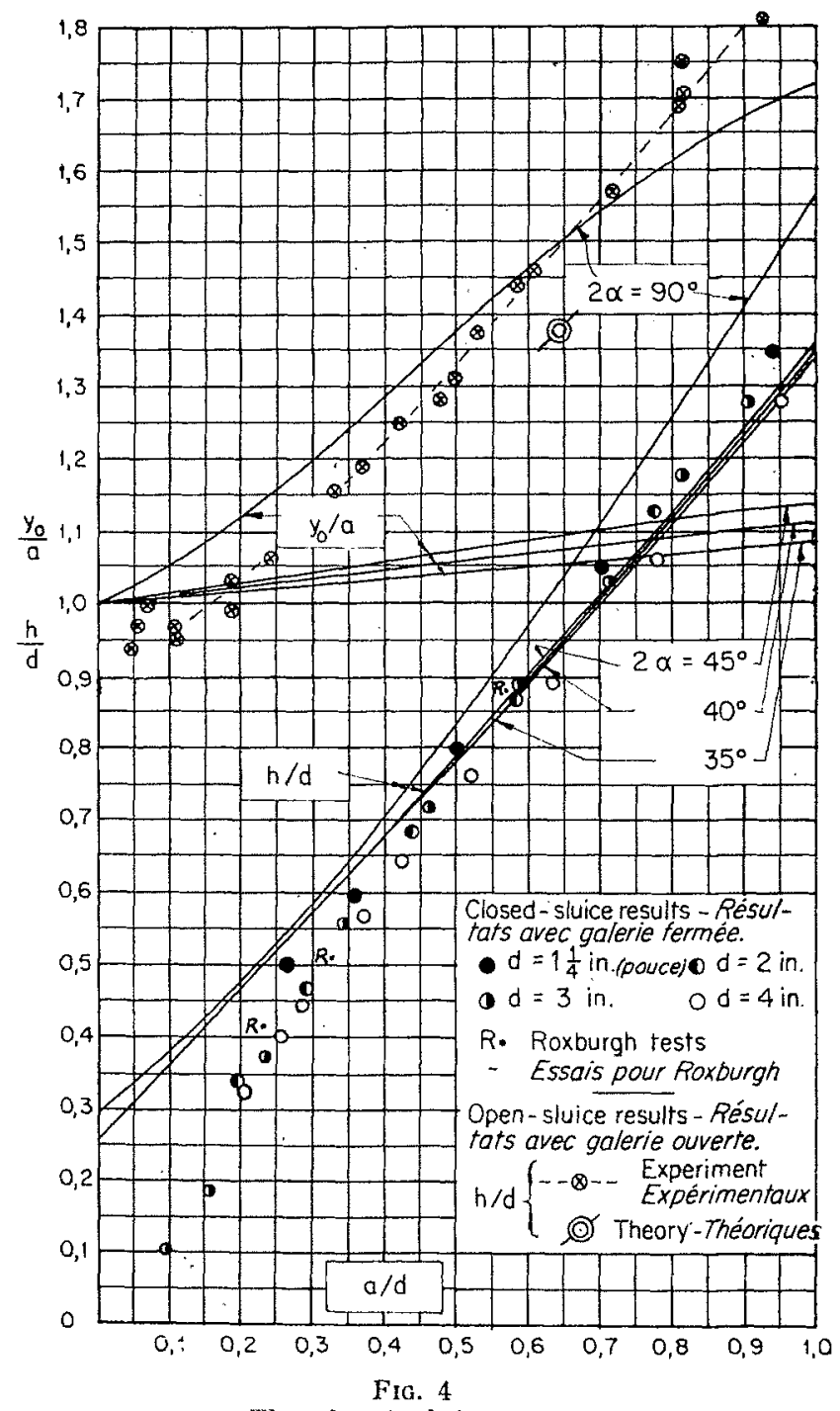

The closed sluice case.

Variation of $y_{0} / a$ and $h / d$ with $a / d$. Galerie fermée.

Variation de $\mathrm{y}_{0} / \mathrm{a}$ et de $\mathrm{h} / \mathrm{d}$ en fonction de a/d. 


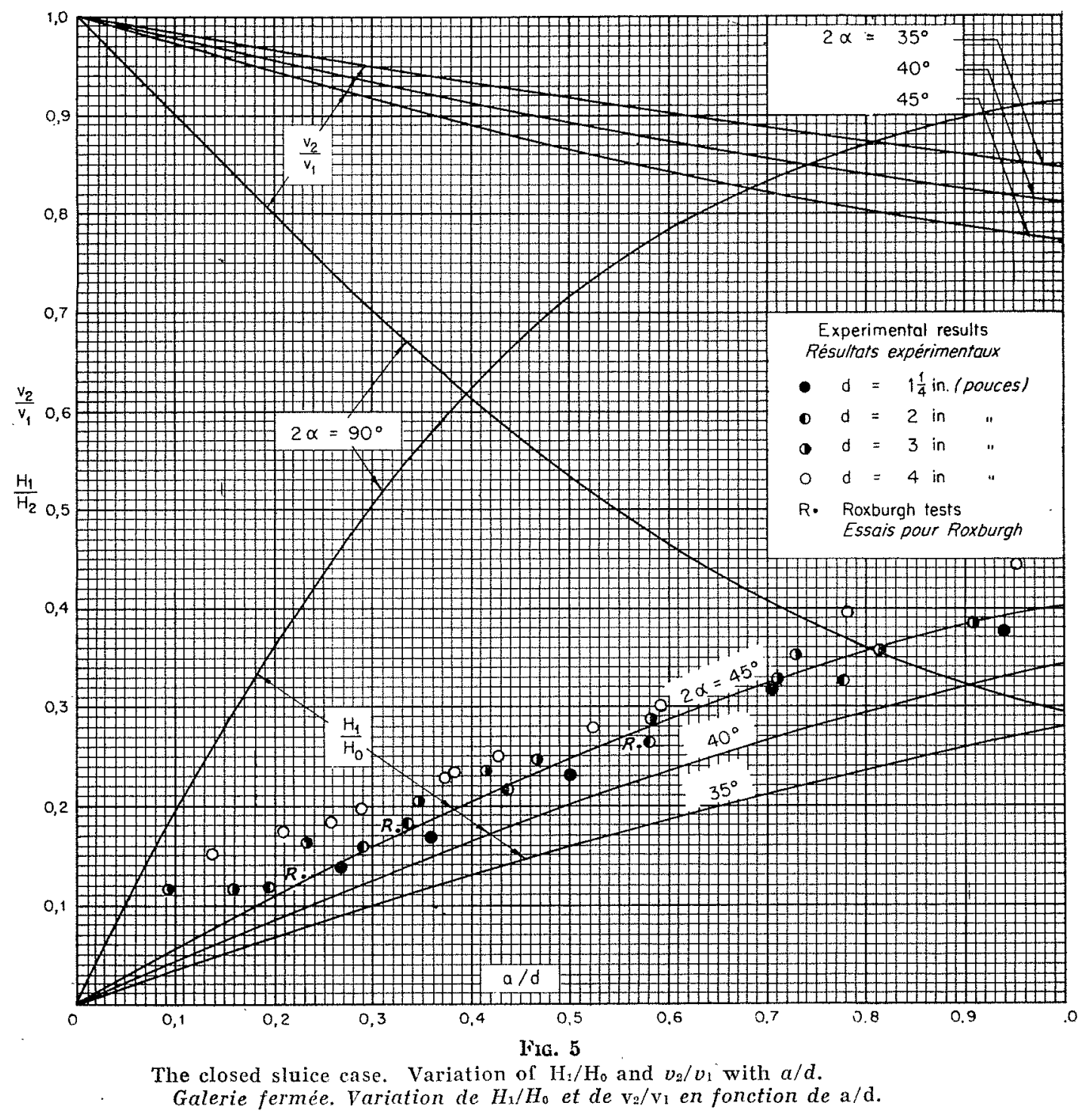

Also, from the boundary conditions at $\mathrm{E}$, and from the well known result:

$$
\mathrm{F}\left(k, \frac{1}{k}\right)=\mathrm{K}+i \mathrm{~K}^{\prime}
$$

where $\mathrm{K}^{\prime}$ is taken with respect to the complementary modulus $k^{\prime} \doteq \sqrt{1-k^{2}}$, we obtain:

$$
\frac{v_{1}}{v_{2}}=e^{\alpha \mathrm{K} / \mathrm{K}}
$$

We consider now the use of equation (5) in exploring regions of particular interest; in all cases values of $k$ are first taken from tables (2), and values of $l / a$ and $v_{1} / v_{2}$ then obtained from equations (2) and (5). The particulär regions are:

\section{(i) The line of symmetry $\mathrm{OH}$.}

This line is the imaginary axis on both the $w$ and $\zeta$ planes, and the real axis on the T-plane. Using the well-known transformation

$$
\mathrm{F}(k, i \eta)=i \mathrm{~F}\left(k^{\prime}, \eta / \sqrt{\left.1+\eta^{2}\right)}\right.
$$

and equations (1) and (3), we obtain:

$$
\mathrm{T}=\log \frac{v_{1}}{v}=\frac{x}{\mathrm{~K}} \mathrm{~F}\left(k^{\prime}, \cos \frac{\pi \psi}{2 v_{1} a}\right)
$$

From this $v-\psi$ equation a $v-y$ relationship can be obtained by numerical tabulation using the equation $\Delta y=\Delta \psi / v$; hence the pressure distribution along $\mathrm{OH}$, the total thrust $\mathrm{F}^{\prime \prime}$ and the bending moment $\mathrm{M}$ about $\mathrm{O}$, and the distance $\bar{y}$ of the centre of thrust from $O$. The following dimensionless measures of these quantities:

$$
\mathrm{F}^{\prime}=\frac{\mathrm{F}}{\frac{1}{2} \rho v_{1}^{2} a}, \quad \mathrm{M}^{\prime}=\frac{\mathrm{M}}{\frac{1}{2} \rho v_{1}^{2} a^{2}}, \quad \ddot{y}^{\prime}=\frac{\bar{y}}{a}=\frac{\mathrm{M}^{\prime}}{\mathrm{F}^{\prime}}
$$

are plotted in Figure 3 against the ratio $a / d$ for a number of values of $\alpha$. The same tabulation yields values of $y_{0} / a$ (Fig. 1), plotted in Figure 4 against $a / d$, and the head ratio $\mathrm{H}_{1} / \mathrm{H}_{0}$ (Fig. 1), equal to $1-\left(v_{2} / v_{1}\right)^{2}$, is plotted in Figure 5, along with $v_{2} / v_{1}$, against $a / d$. 


\section{(ii) The line EOF.}

Along this line $\zeta$ is real and greater than $1 / k$; $w$ is real and equal to $v_{2} s$, where $s$ is the distance along the stream line measured from 0 . From equations (1), (3), and the standard transformation:

for

$$
\mathbf{F}(k, x)=i \mathrm{~K}^{\prime}+\mathbf{F}\left(k, \frac{1}{k x}\right)
$$

we obtain, setting $w / v_{2} l=s / l=\varphi^{\prime}$ :

$$
\mathrm{T}=\log \frac{v_{1}}{v_{2}}-\frac{i \alpha}{\mathrm{K}}, \mathrm{F}\left\{k, \frac{1}{k} \tanh \left(\boldsymbol{s}^{\prime} \tanh ^{-1} \mathrm{k}\right)\right\}
$$

whence:

$$
\frac{\theta}{\alpha}=\frac{1}{\mathrm{~K}} \mathrm{~F}\left\{k, \frac{1}{k} \tanh \left(\varphi^{\prime} \tanh ^{-1} k\right)\right\}
$$

This equation gives $s-\theta$ relationship for the curve EOF from which an $x-y$ relation can be obtained by numerical tabulation. Hence the sluice depth $d$, which (Fig. 2) is given by:

$$
d=2 x_{m} \sin \alpha
$$

and hence the ratio $a / d$, which is used in Figures 3,4 , and 5 as the independent variable which the designer is assumed to know in advance. The length $h$ (Fig. 1) is readily found from the geometry of the curve and from $y_{0}$; the ratio $h / d$ is plotted against $a / d$ in Figure 4 .

By differentiation from equation (9) we obtain the radius of curvature $r$ anywhere on EOF. It is :

$$
\begin{aligned}
& r=\frac{a}{\alpha} \frac{2 K k}{\pi} e^{\alpha K^{\prime} / K} \cosh \left(\varphi^{\prime} \tanh ^{-1} k\right) \times \\
& \times \sqrt{1-\frac{1}{k^{2}} \tanh ^{2}\left(\varphi^{\prime} \tanh ^{-1} k\right)}
\end{aligned}
$$

At the point $O, \varphi^{\prime}=0$, and

$$
r=x_{2}=\frac{a}{\alpha} \frac{2 \mathrm{Kl}}{\pi} e^{\alpha \mathrm{K}^{\prime} / \mathrm{K}}
$$

For the low values of $a / d(<1)$ normally met in practice, $k$ is very close to unity, so from (11) it is clear that $r$ is very close to $r_{2}$ over a wide band in the centre of the curve EOF.

\section{(iii) The line DHC.}

Along this line $\zeta$ is real and numerically less than unity; $T$ is pure imaginary. If $s$ is the distance measured along the streamline from $H$, and $s^{\prime}=s / a$, then since $\downarrow=v_{1} \alpha$,

$$
w=v_{1} a\left(s^{\prime}+i\right)
$$

whence from (1) and (3):

$$
\frac{\theta}{\alpha}=\frac{F\left[k, \tanh \left(\pi s^{\prime} / 2\right)\right]}{\mathrm{K}}
$$

Differentiation leads to an expression for the radius of curvature $r$ :

$$
r=\frac{a}{a} \cdot \frac{2 \mathrm{~K}}{\pi} \cosh \frac{\pi s^{\prime}}{2} \sqrt{1-k^{2} \tanh ^{2}\left(\pi s^{\prime} / 2\right)}
$$

At the point $\mathrm{H}, s^{\prime}=0$, and

$$
r=r_{1}=(a / \alpha)(2 \mathrm{~K} / \pi)
$$

On this curve, as on EOF, the closeness of $k$ to unity means that there is a wide band in the centre with $r$ substantially constant and equal to $r_{1}$.

\section{The free vortex approximation.}

Another interesting approximation occurs when $k$ is very close to unity. From equations (12) and (15) we have:

$$
\frac{r_{2}}{r_{1}}=k e^{\alpha \mathrm{K}^{\prime} / \mathrm{K}}=k \frac{v_{1}}{v_{2}}
$$

from equation (5). Thence:

$$
\frac{r_{2} v_{2}}{r_{1} v_{1}}=k
$$

and if $k$ is close to 1 the product $v r$ is approximately constant over the whole of $\mathrm{OH}$, as in a free vortex. The flow situation can then be very simply explored if either $r_{1}$ or $r_{2}$ is known initially. If $r_{1}$ is known we obtain $r_{2}$ by calculating the discharge across the line $\mathrm{OH}$. It is equal to:

$$
v_{1} a=\int_{r_{1}}^{r_{2}} v d r=\int_{r_{1}}^{r_{2}} \frac{v_{1} r_{1}}{r} d r=v_{1} r_{1} \log \frac{r_{2}}{r_{1}}
$$

whence:

$$
r_{2}=r_{1} e^{a / r_{1}}
$$

By integrating the pressure coefficient across $O H$ we obtain

$$
p^{\prime}=1-\left(v / v_{1}\right)^{2}
$$

$$
\mathrm{F}^{\prime}=\frac{\mathrm{F}}{\frac{1}{2} v_{1}^{2} a}=\frac{\left(r_{2}-r_{1}\right)^{2}}{a r_{2}}
$$

and by integrating the moment of this pressure about $\mathrm{O}$, we obtain :

$$
\mathrm{M}^{\prime}=\frac{\mathrm{M}}{\frac{1}{2} \rho v_{1}^{2} a^{2}}=\frac{\left(r_{2}-r_{1}\right)\left(r_{2}-3 r_{1}\right)+2 r_{1} a}{2 a^{2}}
$$

whence:

$$
\bar{y}^{\prime}=\frac{\mathrm{M}^{\prime}}{\mathrm{F}^{\prime}}=\frac{r_{2}\left(r_{2}-3 r_{1}\right)}{2 a\left(r_{2}-r_{1}\right)}+\frac{r_{1} r_{2}}{\left(r_{2}-r_{1}\right)^{2}}
$$

Equations $(18,19,20)$ are plotted in Figure 3 as broken lines; they show that the free-vortex approximation is in quite good agreement with the complete theory when $a / d$ is less than about 0.8 .

The approximation does not stand completely on its own, for the complete theory is still needed to supply the initial value of $r_{1}$ or $r_{2}$. However in the "solid toe" case, where EOF is a solid boundary of known radius, the free vortex theory would appear to be directly applicable. 
It will be seen in the second paper just how accurate and applicable the theory is in this case.

\section{The range of the design parameters. and the use of the results.}

Numerical results are given in Figures 3, 4, and 5 for four values of the total deflection angle $2 \alpha:-35^{\circ}, 40^{\circ}, 45^{\circ}$, and $90^{\circ}$. The last value corresponds to a "ski jump", which would hardly be used with an open sluice-way; it is included for the sake of comparison with the solid toe case, to be dealt with in the next paper.

It has been mentioned that $k$ is usually close to 1. Now $k \rightarrow 1$ as $a / d \rightarrow 0$, and in practice $a / d$ seldom exceeds 0.6 , corresponding to

$$
\text { for } \quad 2 \alpha=45^{\circ} \text {. }
$$

Results are given for values of $a / d$ up to 1 , which is most unlikely to be exceeded in practice. Even for this value, $k=0.927$ for $2 \%=$ $45^{\circ}$.

Use of the transformations $(6,8)$ for imaginary and complex values could to some extent have been avoided by using the values tabulated and plotted in reference [3].

It is assumed that the following information will give the designer sufficient guidance for the design of the side wall reinforcing:

1. The position of the points $O$ and $H$, given by the values of $h / d$ and $y_{0} / a$ (Fig. 4).

2. Pressure distribution and bending moment along $\mathrm{OH}$, given by Figure 3 and assumed applicable to a strip of unit width lying along $O H$.

3 . The hydrostatic pressure in the region below EOF, given by Figure 5 .

4. Enough information to sketch the curves EOF and DHC. Because $k$ is so close to 1 , these curves may be approximated by circular ares, drawn through the points $\mathrm{O}$ and $\mathrm{H}$ and tangential to the boundaries $\mathrm{AE}, \mathrm{FB}$, and the upstream and downstream water surfaces.

The forces and moments given by Figure 3 derive only from the reduction in velocity along
HO, and must be added to those arising from hydrostatic pressure due to the depth of $O$ below H. Figure 6 shows how the dynamic thrust

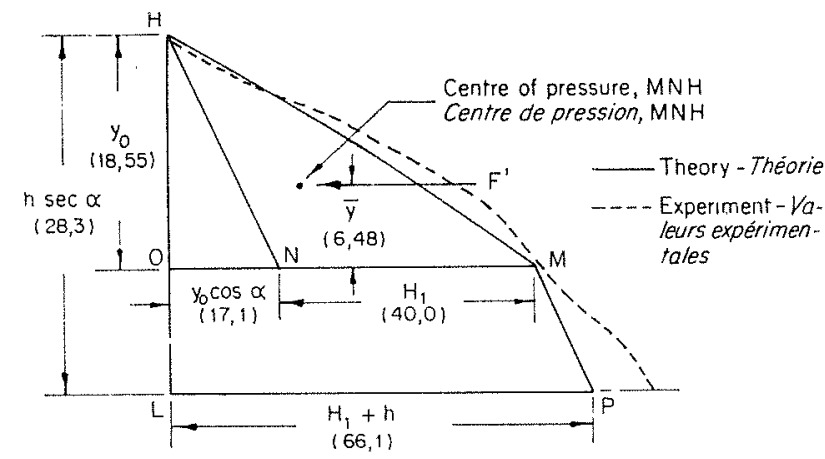

FIG. 6

The closed sluice case.

Distribution of pressure head along LOH. The figures given are in feet and apply to the Roxburgh model tests, $Q=51,100$ cusecs. Galerie fermée.

Répartition de la hauteur de pression suivant LOH. Les valeurs sont indiqueses en pieds et proviennent des essais sur modèle effectués pour Roxburgh. $Q=1446 \mathrm{~m} /{ }^{a} \mathrm{~s}$.

given by Figure 3 , represented by the region $\mathrm{MNH}$, is added to the hydrostatic thrust represented by HON and OMPL.

The heads $\mathrm{H}_{1}$ and $\mathrm{H}_{0}$ must be measured from some point of zero pressure, i.e. on the free surface DHC. A logical choice for such a median point (of average velocity) is the point $\mathrm{H}$; in Figure $5 \quad \mathrm{H}_{1}$ and $\mathrm{H}_{0}$ are plotted according to this choice of base level. Given $\mathrm{H}_{0}$ the designer can obtain $v_{1}$ and hence $a$; the means of allowing for energy losses on the spillway surface will be discussed in the section on experimental results.

Figures 3,4 , and 5 also include values for $a / d=\infty$, i.e. with a sharp angle at the base of the spillway. In this case $k=0$, and the elliptic integral degenerates to an inverse sine. The solution of the problem is a special case of equation (6), viz.

$$
\mathrm{T}=\log \frac{v_{1}}{v}+i \theta=\frac{2 i \alpha}{\pi} \sin ^{-1}\left(\operatorname{coth} \frac{\pi \omega}{2 v_{1} a}\right)
$$

\section{3. - TUNNEL GATE OPEN}

\section{Theoretical solution.}

We consider now the case in which the tunnel gate is open with water discharging through the tunnel as well as down the face of the spillway; this operation could conceivably occur during an emergency draining of the lake. In particular it is desirable to know:

1. Whether the bending moment on the sidewalls is greater or less than when the tunnel gate is closed;

2. To what extent the flow coming down the 
spillway face suppresses the flow coming through the tunnel.

The flow situation is shown in Figure 7 (a). For a solution to be possible we must assume not only that the water has negligible viscosity, but that the two streams have the same total energy. This assumption seems likely to be true in practice, since both streams start with the same total energy, and must undergo losses of the same order on their way to the spillway toe.

The two streams are separated by a streamline originating, at the point $\mathrm{E}$. This point will be a stagnation point in both streams, since if it were a stagnation point in one stream only there would be a pressure discontinuity. The streamline through $\mathrm{E}$ is therefore tangential to neither AE nor DE.

As in the previous analysis the effect of gravity is neglected; the velocity along the free stream line $\mathrm{AB}$ is $v_{1}$, and the velocity within the tunnel is $b_{2}$. The lengths $a$ and $d$ are defined as before, but in this case it is more convenient to define the $\mathrm{X}$-axis as being parallel to $\mathrm{DB}$. The discharges per unit width of the two streams
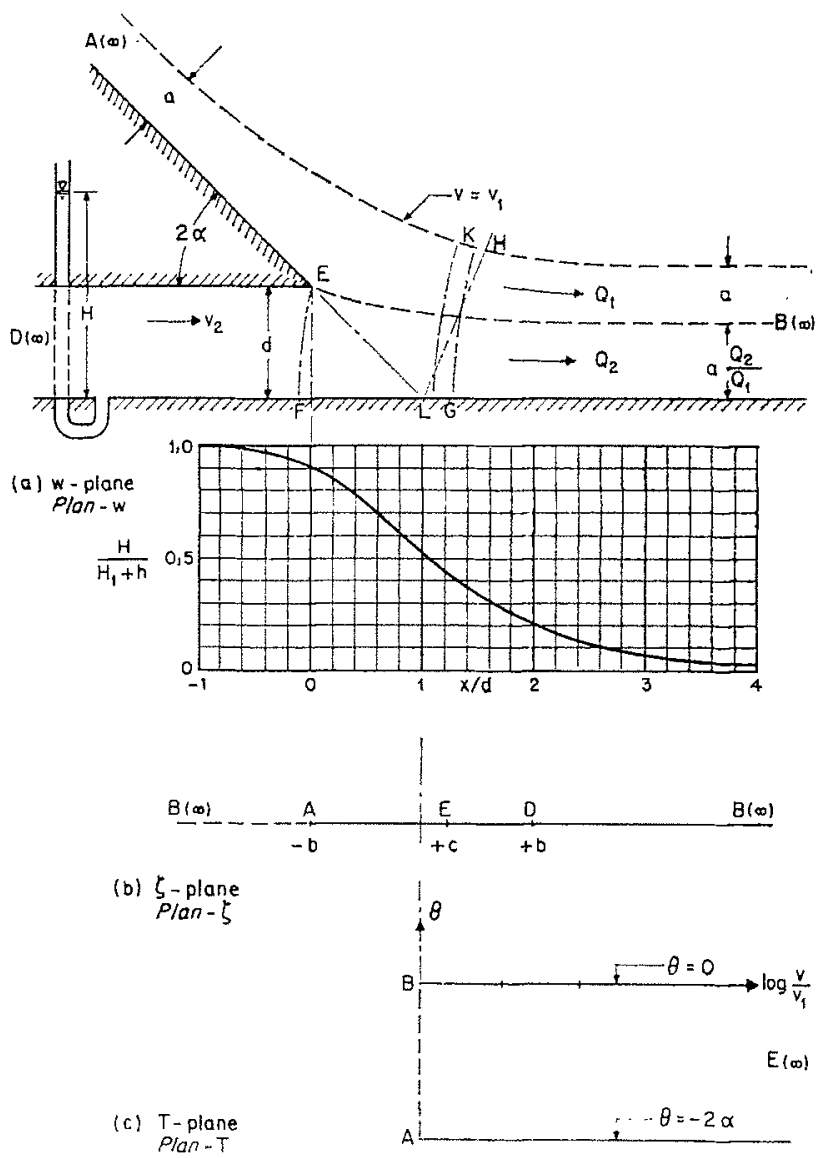

FIG. 7

The open sluice case.

Basic flow situation and mapping problem. Galerie ouverte. Schéma d'écoulement et problème de représentation. are $\mathrm{Q}_{1}=v_{1} a$ on the spillway face and $\mathrm{Q}_{2}=v_{2} d$ in the tunnel.

Figure $7(b)$ shows the intermediate $\zeta$ plane with the point $B$ at infinity and $A$ and $D$ symmetrically placed about the origin. The lengths $b$ and $c$ are as yet unknown. Figure 7 (c) shows the plane of $\mathrm{T}=\log \left(v_{1} / v\right)+\mathrm{i} \theta$. Solid boundaries are shown by full lines, free boundaries by broken lines.

On the $\zeta$ plane the flow situation is a source of strength $2 Q_{1}$ at $A$ and source of strength $2 Q_{2}$ at $D$. The $w-\zeta$ equation is

$$
w=\frac{\mathrm{Q}_{1}}{\pi} \log (\zeta+b)+\frac{\mathrm{Q}_{2}}{\pi} \log (\zeta-b)
$$

whence

$$
\frac{d w}{d \zeta}=\frac{Q_{1}}{\pi(\zeta+b)}+\frac{Q_{2}}{\pi(\zeta .-b)}
$$

At the point $\mathrm{E}, d w / d \zeta=0$, whence:

$$
\frac{c}{b}=\frac{\mathrm{Q}_{1}-\mathrm{Q}_{2}}{\mathrm{Q}_{1}+\mathrm{Q}_{2}}
$$

For the $\mathrm{T}-\zeta$ relation, the Schwarz-Cristoffel theorem yields:

$$
\begin{aligned}
\mathrm{T} & =\mathrm{G} \int \frac{d \zeta}{(\zeta-c) \sqrt{\zeta+b}}+\mathrm{L} \\
& =2 \mathrm{G} \tanh ^{-1} \sqrt{\frac{\zeta+b}{b+c}}+\mathrm{L}
\end{aligned}
$$

The boundary conditions at $\mathrm{A}$ and $\mathrm{B}$ show that $\mathrm{L}=-2 i \alpha, \mathrm{G}=2 \alpha / \pi$, whence :

$$
\mathrm{T}=\frac{4 \alpha}{i} \tanh ^{-1} \sqrt{\frac{\zeta+b}{b+c}}-2 i \alpha
$$

At the point $\mathrm{D}, v=v_{2}$ and $\zeta=+b$, whence from (25):

$$
\sqrt{\frac{2 b}{b+c}}=\frac{1+\left(v_{1} / v_{2}\right)^{\pi / 2 \alpha}}{1-\left(v_{1} / v_{2}\right)^{\pi / 2 \alpha}}
$$

Substituting for $c / b$ from (23), we obtain with some further manipulation:

$$
\mathrm{Q}_{1} / \mathrm{Q}_{2}=\frac{1}{4}\left\{\left(v_{1} / v_{2}\right)^{\pi / 4 \alpha}-\left(v_{2} / v_{1}\right)^{\pi / 4 a}\right\}^{2}
$$

and since $\mathbf{Q}_{1} / \mathrm{Q}_{2}=v_{1} a / v_{2} d$, equation (26) will yield $a / d$ as a function of $v_{1} / v_{2}$, and $\mathrm{Q}_{1} / \mathrm{Q}_{2}$ as a function of $a / d$.

\section{The suppression of the tunnel flow}

Let $Q_{0}$ be the flow that would go through the tunnel if there were no flow down the spillway face. In this case the tunnel velocity would be $v_{1}$, so that $\mathrm{Q}_{0}=v_{1} d$. It is of interest to determine whether the total $\left(Q_{1}+Q_{2}\right)$ is greater or less than $Q_{0}$; if it is less, the release of water over the spillway would actually reduce the 
total flow. We consider the typical case $\alpha=\pi / 8$, whence $\pi / 4 \alpha==2$. Now:

$$
\begin{aligned}
\frac{\mathrm{Q}_{1}+\mathrm{Q}_{2}}{\mathrm{Q}_{0}} & =\frac{v_{1} a+v_{2} d}{v_{1} d}=\frac{a}{d}+\frac{v_{2}}{v_{1}}=\frac{v_{2}}{v_{1}}\left(1+\frac{\mathrm{Q}_{1}}{\mathrm{Q}_{2}}\right) \\
& =\frac{1}{4} \frac{v_{2}}{v_{1}}\left\{\left(\frac{v_{1}}{v_{2}}\right)^{2}+\left(\frac{v_{2}}{v_{1}}\right)^{2}\right\}^{2}
\end{aligned}
$$

from (26). Now it can easily be shown that the above expression has a minimum value of 0.940 when $v_{2} / v_{1}=0.880$, i.e. $a / d=0.060$. In fact it is less than unity over the range $0.77<v_{2} / v_{1}<1$, i.e. $0<a / d<0.23$. (We note that as $\mathrm{Q}_{1} \rightarrow 0$, $v_{2} / v_{1} \rightarrow 1$ and $a / d \rightarrow 0$. For $\left.Q_{1}>0, v_{2} / v_{1}<1\right)$.

The conclusion is an interesting one: that there is a range of values of $a / d$ for which $\mathrm{Q}_{1}+\mathrm{Q}_{2}>\mathrm{Q}_{0}$, i.e. the spillway flow suppresses and reduces the tunnel flow by an amount greater than the spillway flow itself. The general trend is shown in Figure 8 , in which $Q_{1} / Q_{2}$ and $\left(Q_{1}+Q_{2}\right) / Q_{0}$ are plotted against $a / d$ for $2 \alpha=35^{\circ}, 40^{\circ}, 45^{\circ}$.

We now consider this conclusion in relation to the tunnel's function of draining the lake in an emergency. Operation of the spillway will increase the total flow only when $a / d>0.2$ on average (Fig. 8). Since $a \cong Q_{1}$ this condition will be met only when $Q_{1}$ is fairly large and the lake level is high; when the water falls below a certain fairly high level spillway operation will contribute nothing.

The conclusion is that spillway operation increases the flow by margins of the order of $20 \%$ (Fig. 8) over a small percentage of the total range over which the lake is to be lowered. Therefore spillway operation reduces by only a very small percentage the time in which the whole lake can be drained. In one case calculated by the writer, the margin was only about $3 \%$.

\section{Velocity and pressure distribution.}

The analysis has led to simple equations relating discharge ratios to the ratio $a / d$; however it is much more difficult to explore the velocity and pressure distribution near the sluice opening because this time LH is not an axis of symmetry. 'To explore the region LH one must trace the equipotential $\mathrm{EF}$, thence the stream line $\mathrm{FG}$, thence typical equipotentials $G K$ up to the free surface (Fig. 7).

The tracing process consists of the numerical solution of equations $(22,23,25)$ for the increments $\Delta s=\Delta \varphi / v$ and $\Delta n=\Delta \downarrow / v$. Calculations made for the case $x=\pi / 8, Q_{1}=Q_{2}$, whence

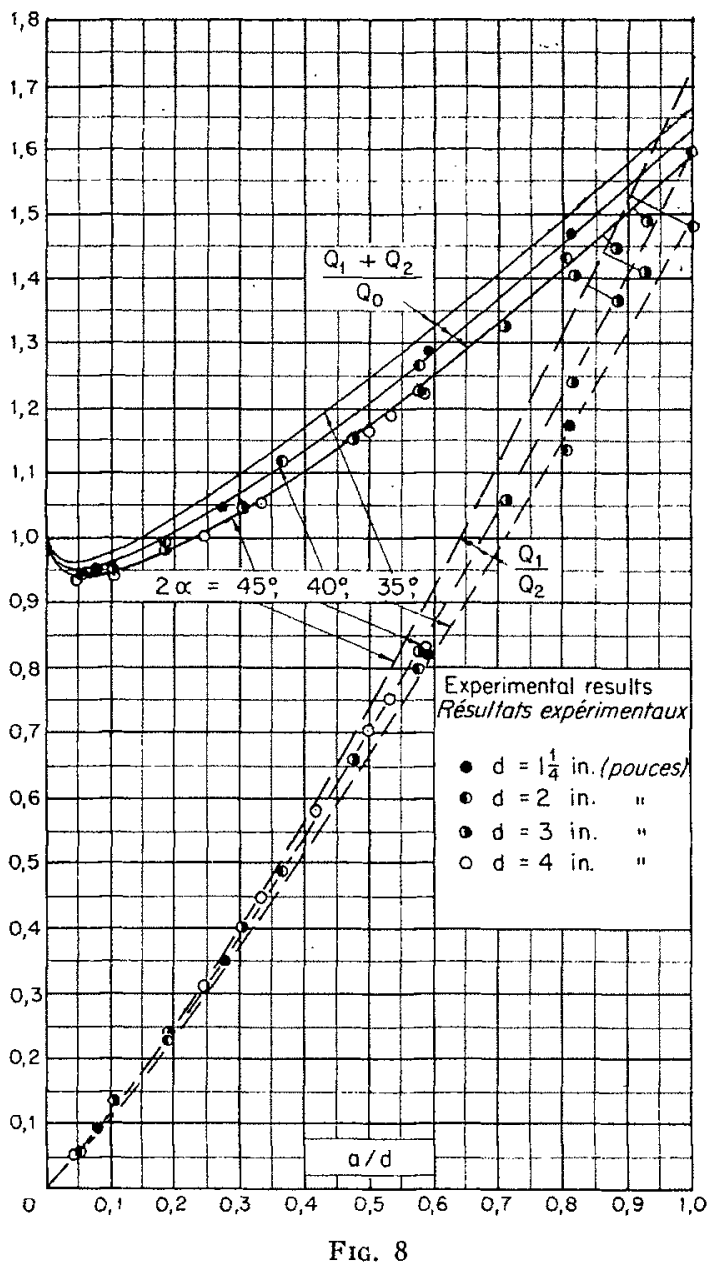

The open sluice case. Discharge relationships. Galerie ouverte. Courbes de détit.

$a / d=0.64 .4$, showed that the bending moment near L.H was more than twice as much as for the closed-sluice case. For this reason, and because open-sluice operation offers so little benefit by way of increased discharge, this forn of operation is not recommended and the full investigation of pressure distribution will not be proceeded with in this paper.

However, experimental values of the height $h$ are given in a later section, and the pressure head ratio $\mathrm{H} /\left(\mathrm{H}_{1}+h\right)$ on the floor of the sluice is plotted in Figure 7 (a) for the case $\alpha=\pi / 8$, $a / d=0.644$. From these data it is possible, in any particular case, at least to make an outline sketch of the flow situation and the pressure distribution by deducins the pressure within the sluice from the value of $\mathrm{Q}_{1} / \mathrm{Q}_{2}$ (Fig. 8) and assuming that the pressure distribution on the floor will be of approximately the same form as shown in Figure $7(a)$. 


\section{4. - EXPERIMENTAL RESULTS}

Tests were carried out in a horizontal channel 6 inches wide with walls of transparent plastic. A model spillway block of total height $11 \%$ inches, and a face making an angle of $45^{\circ}$ with the horizontal, was mounted in the channel with its hase at a distance $d$ above the channel bed, making an open sluiceway. The depth $d$ of the sluice was set at $1 \frac{1}{1}, 2,3$, and 4 inches: for each value of $d$ one scries was run with the sluice closed, and another with the sluice open and water discharging over the spillway and through the sluice.

\section{Closed sluice results : Author's tests.}

For each test, the discharge was measured volumetrically; also measured were the water level behind the spillway, the depth $h$ (Fig. 1) and the pressure head inside the sluice-this last from one manometer reading well back in the sluice, remote from any local disturbances caused by the shear stress along the surface EOF. From these measurement $\mathrm{H}_{1}$ and $\mathrm{H}_{0}$ were readily obtained (Fig. 1) and $a$ was deduced from the relation:

$$
a=\mathrm{Q} / b v_{1}=\mathrm{Q} / b \sqrt{2 g \mathrm{H}_{0}}
$$

where $b$ is the width of the channel. Energy loss down the spillway face was neglected, as were the characteristic plumes which developed at the sidewalls; these plumes must he substantially at atmospheric pressure and would not contribute to the thrust on the sidewalls. The question of energy loss will be discussed at a later stage.

Experimental values of $h / d$ vs. $a / d$ are plotted on Figure 4. For the closed sluice, agreement with theory is quite good when $a / d>0.4$; below that value the experimental points tend towards the origin of the graph, presumably because in this region the sluice is not full of water and the assumptions made in the analysis are no longer valid.

The experimental values of $H_{1} / H_{0} \quad$ vs.a/d, plotted in Figure 5, show good agreement with theory for the $1 \frac{1 / 4}{4}$ and 2 inch sluices, and not such good agreement for the 3 and 4 inch sluices. The reason would seem to be that when $d / \mathrm{H}_{0}$ is small, the assumption of constant velocity along the upper free surface is very close to the truth; but when $d / H_{0}$ is larger gravity makes the velocity $v_{1}$ vary appreciably over the region near the sluice opening and the choice of a base level from which to measure $\mathrm{H}_{1}$ and $\mathrm{H}_{0}$ becomes a doubtful matter.

In particular, the choice of the point $H$ is somewhat arbitrary, but one may largely compensate for any errors due to this arbitrary choice by considering how the sum $\left(\mathrm{H}_{1}+h\right)$ behaves. This sum may be obtained for all values of $d$; it is here tabulated for the typical case $d=3$ inches.

Values of $\left(\mathrm{H}_{1}+h\right)-f t$, for $d=3 \mathrm{in}$.

\begin{tabular}{|c|c|c|}
\hline \multicolumn{2}{|c|}{$\mathrm{H}_{1}+h$} & \\
\hline & & $a / d$ \\
Theory & Experiment & \\
\hline & & \\
\hline 0.161 & 0.187 & 0.094 \\
0.230 & 0.255 & 0.160 \\
0.304 & 0.325 & 0.231 \\
0.415 & 0.440 & 0.344 \\
0.534 & 0.565 & 0.464 \\
0.648 & 0.665 & 0.580 \\
0.768 & 0.774 & 0.711 \\
0.854 & 0.860 & 0.810 \\
0.928 & 0.934 & 0.906 \\
& & \\
\hline
\end{tabular}

Even for the lower values of $a / d$, agreement between theory and experiment is markedly better than it is for either $\mathrm{H}_{1} / \mathrm{H}_{0}$ or $h_{1} / d$, suggesting that errors of opposite sign have cancelled each other.

Agreement is within $5 \%$ and therefore satisfactory for design purposes when $a / d>0.3$, a figure which will usually be exceeded at maximum discharge, which is the critical design condition.

The corresponding figures for other values of $d$ show even better agreement for $d<3$ inches but are less satisfactory at $d=4$ inches. We may conclude that agreement is satisfactory for $d / \mathrm{H}_{0} \leqslant 0.2$ approx.

It must be emphasised that the above tabulation applies to one experimental set up only; a general dimensionless representation of

$$
\left(\mathrm{H}_{1}+h\right)
$$

is not possible since $H_{1}$ is related to $H_{0}, h$ is related to $d$, and the ratio $d / H_{0}$ varies. 
Ministry OF WORKS TESTS - ROXBURGH FYYRo

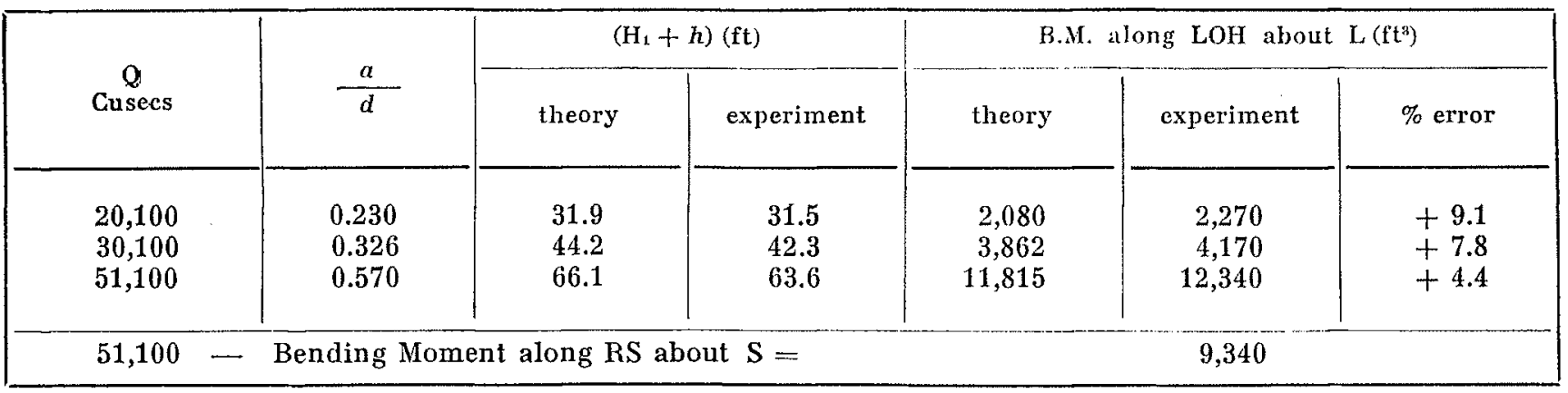

\section{Closed sluice results : \\ Roxburgh hydro tests.}

There remains the question of how the pressure may be distorted near line EOF by shear stress or by local gravity effects. Reference is now made to some tests done by the New Zealand Ministry of Works in the form of spillway model studies of the Roxburgh hydro-electric project. In this scheme the spillway angle is $45^{\circ}$, as in the tests described above; in fact points representing them are plotted on Figures 4 and 5 .

The tests included a most comprehensive set of sidewall pressure measurements, which considerably clarified the whole picture of events. Figure 9 shows the flow profile and pressure contours for the case $a / d=0.57$, and the pressure contours predicted by the theory. Within the sluice the two sets of contours are almost coincident, but downstream of the line of symmetry LOH there is a distinct concentration of pressure which is not predicted by the theory, but is clearly due to gravity-induced acceleration of the jet, producing higher velocities and centripetal pressures downstream of $\mathrm{LOH}$.

The existence of this "bulb" of pressure does not neccessarily impair the usefulness of the theory for design purposes; the important question is that of the bending moment in certain key regions such as the line $\mathrm{LOH}$, and the crucial test of the theory is whether it predicts this bending moment with reasonable accuracy. We can settle the matter by plotting the measured and predicted pressure distribution along $\mathrm{LOH}$; this is done to scale in Figure 6, already referred to as a guide to the use of $\mathrm{M}^{\prime}, \mathrm{F}^{\prime}$, etc.

The case shown in Figure 9 is the one plotted in Figure 6. The prototype dimensions are: $d=30 \mathrm{ft}, \quad b=31 \mathrm{ft}$. average (actually tapered slightly in plan), lake level $170.1 \mathrm{ft}$ above sluice invert, discharge $Q=51,100$ cusecs. Hence $a=17.1 \mathrm{ft}$., $h=26.1 \mathrm{ft}$. (by trial from equation (28) and Figure 4) and $a / d=0.57$. From Figures 4 and $5, \mathrm{H}_{1}=40.00 \mathrm{ft}$. and $y_{0}=18.55 \mathrm{fl}$. From Figure $3, \mathrm{~F}^{\prime}=0.162$ and $\ddot{y}^{\prime}=0.379$; hence the pressure profile in Figure 6 is constructed. It is seen that the two profiles are remarkably close together.

The above table summarizes results for this case and for two other cases, $Q=20,100$ and 30,100 cusecs. Pressures are expressed in feet head of water, and bending moments in $\mathrm{ft}^{3}$, i.e. excluding the specific weight $\%$.

For $Q=51,100$, cusecs the agreement between theory and experiment is remarkably good; it

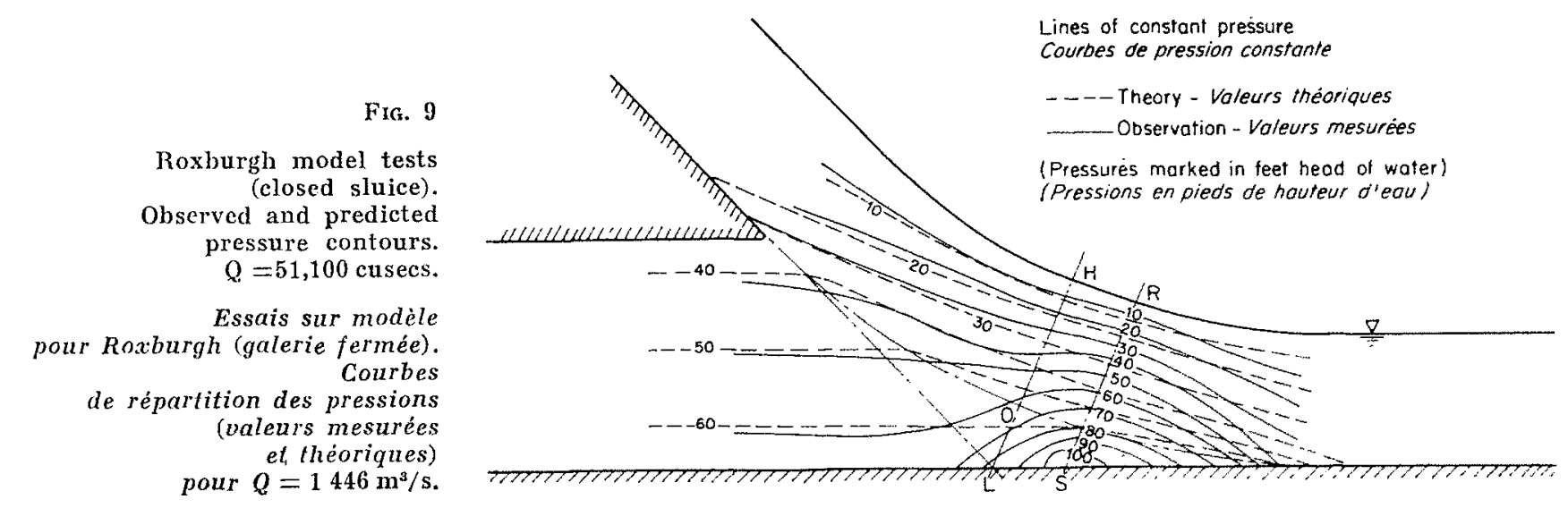


is not quite so good for the lower discharges, because the pressure contours (not shown here) indicate that the pressure bulb moves upstream with diminishing discharge until at $Q=20,000$ cusecs $(a / d=0.23)$ it is centred at the point $\mathrm{L}$. The table shows that at 51,100 cusecs the bending moment along $\mathrm{RS}$, i.e. through the centre of the pressure bulb, is greater than predicted by the theory but is much less than along the line $\mathrm{OH}$.

But even at the lower flows agreement is quile good, because the value of $h$ is substantially less than the one predicted by the theory. The effect of gravity is not only to produce the local bulb of pressure shown in Figure 9 but also to depress the lower streamline EOF; the two effects tend to cancel each other, explaining the good agreement between actual and theoretical values of $\left(\mathrm{H}_{1}+h\right)$ as well as of bending moment.

Final discussion of these results will be made in the conclusions presented at the end of this paper.

No allowance has been made for head loss down the spillway face; in fact any such correction will make very little difference to the computation of bending moment. For the effect of such a correction is to reduce the effective value of $\mathrm{H}_{0}$, and equation (28) shows that, for given $b$ and $\mathrm{Q}, a^{2} \mathrm{H}_{0}$ remains constant whatever value is assumed for $H_{0}$. Now the bending moment is equal to:

$$
\mathrm{M}=\mathrm{M}^{\prime} \gamma^{2} \mathrm{H}_{0}
$$

of which only $\mathrm{M}^{\prime}$ varies as $\mathrm{H}_{0}$ is adjusted. Figure 3 shows that $\mathrm{M}^{\prime} \cong \alpha$ (approx), so that $\mathrm{M} \cong a$ (approx.) Since $a^{2} \mathrm{H}_{0}$ remains constant, a $5 \%$ reduction in $\mathrm{H}_{0}$ will mean only a $21 / 2 \%$ increase in $a$ and hence in $M$. It seems therefore that since head loss is usually less than $5 \%$, except for very spillways, allowance for head loss will make only small variations in $M$, of order of $1-2 \%$.

\section{Existence of splash at low flows.}

All of the preceding material deals with discharges high enough to make the flow pass smoothly from the inclined to the horizontal direction without any splash other than the development of plumes at the side walls.

However at low flows when the jet thickness $a$ is very small and there is little build up of stagnant water in the tunnel, the jet strikes the channel floor directly, with the development of considerable splash, turbulence, and attack on the concrete of the floor. This state of affairs is clearly undesirable in practice; accordingly some runs were made aimed at determining the lower limit of discharge below which splash will occur.
A suitable numerical criterion would seem to be ratio of the jet thickness $a$ to the depth, $\mathrm{H}_{1}+h$, of the stagnant water that develops behind the jet and provides a "cushion" which guides the flow smoothly through the desired change of direction. The experimental runs, which were made at sluice depths of $11 / 4,2$, and 3 inches, did in fact show that this ratio substantially determined whether splash would exist.

T'he results were quite straightforward and details will not be given here. The conclusion was that $\left(\mathbf{H}_{1}+h\right) / a$ has a critical value of $8-10$; since $a$ diminishes more rapidly with decreasing discharge than does $\left(H_{1}+h\right)$, the ratio

$$
\left(\mathrm{H}_{1}+h\right) / a
$$

increases with decreasing discharge and the critical value given is a minimum, above which splash will develop. When $\left(\mathrm{H}_{1}+h\right)>d$, and the stagnant water fills the tunnel, a somewhat higher value of the ratio can be tolerated than when $\left(\mathrm{H}_{1}+h\right)<d$ and the jet has to jump over a gap. To sum up:

If $\left.\left(\mathrm{H}_{1}+h\right)<d,\left(\mathrm{H}_{1}+h\right) / a \ngtr 8\right\}$ If splash is If $\left.\left(\mathrm{H}_{1}+h\right)>d,\left(\mathrm{H}_{1}+h\right) / a \ngtr 10\right)$ to be avoided the calculated value of $\left(\mathrm{H}_{1}+h\right)$ being used in all cases.

\section{Open - sluice results.}

For each test, the discharge was measured volumetrically, and the piezometric head within the sluice was also measured, giving the discharge $Q_{2}$ and hence the spillway discharge $Q_{1}$ by subtraction. (The flow division upstream.of the spillway makes the deduction of $Q_{1}$ from spillway head rather uncertain). The height $h$ of the point $\mathrm{H}$ (Fig. $7 a$ ) above the sluice invert was also measured and plotted on Figure 4. This point was taken-again rather arbitrarily - as the base from which $\mathrm{H}_{0}$ was measured for the determination of the depth a from equation (28). The free discharge $Q_{0}$ is deduced from the obvious equation

$$
\mathrm{Q}_{0}=b d \sqrt{2 g \dot{\mathrm{H}_{0}}}
$$

where $\mathrm{H}_{0}$ is measured upwards from the point E. Since $\mathrm{E}$ is not necessarily level with $\mathrm{H}$, the value of $Q_{0}$ given by (29) will in general be different from that given by (27).

On Figure 8 it is seen that the experimental values of the discharge ratios fit the theoretical curves remarkably well, particularly for the ratio $\left(Q_{1}+Q_{2}\right) / Q_{0}$; the minimum predicted by the theory is clearly established experimentally.

In fact we should expect better agreement between theory and experiment in this case than 
when the tunnel gate is closed, for two reasons; first, there is less change in elevation in the upper streamline, and hence a more nearly constant velocity; second, since the velocity and its first derivative are continuous across the dividing streamline EB, the shear stresses along this line are much smaller than on the line EOF in the closed-gate case.

On Figure 4 the one value of $h / d$ calculated from the theory is substantially (about $10 \%$ ) lower than the line through the experimental points. This disagreement suggests that the effect of gravity-neglected in the analysis-has been to make the lower stream lift the upper stream bodily without changing very much the discharge ratios predicted by the theory. This conjecture raises an interesting question of principle, but it will not be explored further here because of the limited applicability of this flow situation in practice.

\section{5. - CONCLUSIONS}

1. When the tunnel gate is closed, the theory (Figs. 3-6) is in good agreement with experiment for $d / \mathrm{H}_{0} \leqslant 0.2$; above this limit the local effects of gravity make the analysis less accurate. Even when $d / \mathrm{H}_{0} \leqslant 0.2$, there is a concentration of pressure downstream of LOH which is not predicted by the theory; as $a / d$ decreases this "bulb" of pressure moves upstream until at $a / d=0.25$ it is in line with LOH. In no case is the bending moment along $\mathrm{LOH}$ more than $10 \%$ greater than the theory indicates, but for $a / d>0.4$, when the pressure bulb is well downstream of LOH, allowance should be made for a bending moment along RS (Fig. 9) equal to about $75 \%$ of that along LOH.

2. When the tunnel gate is open, the discharge ratios are as predicted by the theory (Fig. 8) but the level of the free surface is somewhat higher. For $a / d<0.23,2 \alpha=45^{\circ}$, the total flow over the spillway and through the tunnel is less than if the tunnel alone were discharging. For $2 \alpha<45^{\circ}$, the critical value of $a / d$ is somewhat less than 0.23. Pressure and velocity distribu- tion is difficult to compute, but the bending moment along $\mathrm{LOH}$ appears to be about twice as much as when the tunnel gate is closed.

3. Flow resistance has little effect on computed values of bending moment, since the product $a^{2} \mathrm{H}_{0}$ remains constant for a given $Q$ even if $\mathrm{H}_{0}$ is reduced by resistance. Just as in flow round submerged bodies, the existence of the boundary layer seems to have little effect in itself on the pressure distribution.

4. The effect of aeration is easily allowed for, using data such as are given by Elavatorski [4]. If aeration increases $a$ by the factor $m,(>1)$ then the specific weight $\gamma$ is reduced by the factor $m$.

Now:

$$
\mathrm{M}=\mathrm{M}^{\prime \prime} \frac{1}{2} \rho v_{1}^{2} a^{2}=\mathrm{M}^{\prime} \gamma \mathrm{H}_{0} a^{2}
$$

where $\mathrm{M}^{\prime} \cong a$ approximately (Fig. 3). Hence $\mathrm{M} \cong \gamma a^{3}$ approx., and if $a$ is replaced by $m a$, and $\gamma$ by $\gamma / m$, then $M$ is increased by the factor $m^{2}$. Similarly $F$ and $\bar{y}$ are each increased by the factor $m$.

\section{6. - ACKNOWLEDGEMENT}

The New Zealand Ministry of Works model tests on the Roxburgh Hydro-electric scheme were performed under the general direction of Mr. F.R. Askin, Chief Engineer (Power). They are quoted here by the permission of Mr. F. M. Hanson, Commissioner of Works, who is hereby thanked accordingly.

\section{REFERENCES}

[1) L. M. Milne-Thomson : Theoretical Hydrodynamics, 3rd ed, MacMillan, 1955, Chap. XI.

[2] G. W. and R.M. Spenceley : Smithsonian elliptic functions tables, Washington, D.C., 1947 (Miscellaneous Collections V. 109).
[3] F. M. Henderson : Elliptic functions with complex arguments, University of Michigan Press (1960).

[4) E.A. Elavatonski : Hydraulic energy dissipators, McGraw-Hill (1959), p. 115. 


\title{
L'écoulement au pied d'un évacuateur de crues
}

\section{I. - DÉVERSOIR COMBINÉ AVEC GALERIE DE DÉRIVATION}

\author{
PAR F. M. HENDERSON, \\ INGÉNIEUR CIVII \\ MATTRE DE CONFÉRENCES A L'UNIVERSITE DE GANTERBURY, \\ CHRISTCHURCH, NOUVELLE-ZÉLANDE \\ (Voir les illustrations dans le texte anglais, p. 728.)
}

\begin{abstract}
Le problème examiné dans cette étude a trait au régime d'écoulement existant au pied d'un déversoir implanté au-dessus d'une galerie ouverte. Les solutions trouvées correspondent $\dot{a}$ deux cas : dans le premier cas, la vanne de la galerie est fermée, de sorte que la galerie est, soit entièrement, soit partiellement, remplie d'eau au repos, et dans le deuxième cas, la vanne de la galerie est ouverte, et l'ean s'écoule a la fois par le déversoir et par la galerie. Les
\end{abstract}

\begin{abstract}
résultats expérimentaux obtenus s'accordent bien avec les données théoriques, à l'exception toutefois de certaines limitations, lesquelles sont d'ailleurs généralement respectées dans la pratique.

Les résultats correspondant au cas le plus souvent rencontré, c'est-à-dire celui du pied de déversoir présentant une surface solide, courbe, et sans ouverture, seront présentés dans une deuxième étude.
\end{abstract}

\section{1. - INTRODUCTION}

I.e problème général considéré dans la présente étude intéresse la transformation au pied d'un déversoir, de l'écoulement incliné en un écoulement horizontal. Les pressions et les moments de flexion auxquels sont soumises les parois latérales du déversoir, dépendent de la répartition de la pression centripète naissant pendant le changement de direction dı jet. Cependant, le problème est rendu plus complexe par le fait que la pression plus élevée, à laquelle sont soumis les filets liquides extérieurs (c'est-à-dire ceux présentant le plus grand rayon de courbure), donne naissance à de plus faibles vitesses, lesquelles provoquent à leur tour un épaississement localisé appréciable du jet; ce phénomène est particulièrement prononcé dans le cas des déversoirs en «cuillère», dans lesquels l'angle de déviation du jet est voisin d'un angle droit.

D’autres complications du problème se pré- sentent également, notamment l'aération et l'évolution d'une couche limite, au cours de l'écoulement de l'eau vers le bas de la lace du déversoir; il est cependant possible de tenir compte de ces phénomènes en connaissant une solution du problème primaire, lequel se résume ainsi : déterminer pour une eau supposée nonvisqueuse et non aérée, les répartitions de vitesses et des pressions, et la mesure dans laquelle le jet s'épaissit localement pendant qu'il s'écoule suivant la surface courbe du déversoir.

Les deux présentes études traitent de ce problème primaire: la première examine le cas d'une canalisation ouverte, située au pied du déversoir; la deuxième étude s'intéresse au cas, plus souvent rencontré, d'une surface courbe solide, sans ouverture, occupant l'angle formé par la face inclinée du déversoir, et l'horizontale.

Le premier cas se présente dans ceux des aménagements hydro-électriques où il convient 
d'implanter l'ouvrage d'évacuation et le canal de dérivation sur le même axe; dans ce cas, ce canal se présente sous la forme d'une galerie aménagée dans la partie inférieure de l'ouvrage d'évacuation. A l'achèvement des travaux de construction, on peut obturer cette galerie, soit par un tampon en béton, soit par une vanne permettant par la suite l'emploi de la galerie comme vidange de secours.

La présente étude s'intéresse au cas du déversoir «à galerie aval ouverte», et examine l'influence de l'entrée ouverte de la galerie sur l'écoulement de l'eau suivant la face du déversoir.

Des solution théoriques sont obtenues pour deux cas : dans le premier, la vanne de la galerie est fermée, et l'eau s'écoule uniquement pardessus la crête du déversoir; dans le deuxième cas, la vanne de la galerie est complètement ouverte, et l'eau s'écoule à la fois par-dessus la crête du déversoir et par la galerie. Des résultats expérimentaux sont présentés pour ces deux cas et s'accordent bien avec les données théoriques.

\section{2. - VANNE DE GALERIE FERMÉE}

\section{Solution théorique.}

Les conditions aux limites sont relativement simples dans ce cas (voir fig. 1). Il existe deux limites libres, DHC et EOF, et, dans la galerie, la masse d'eau en amont de la limite EOF est au repos. La vitesse sera constante, suivant $\mathrm{DHC}$, à condition d'admettre que les phénomènes dus à la pesanteur soient assez faibles pour être négligeables (c'est-à-dire que les variations de la hauteur verticale de la surface DHC, au voisinage du débouché de la galerie, soient faibles devant la hauteur, due à la vitesse, que possède déjà l'écoulement); nous admettrons cette hypothèse dans l'analyse qui va suivre. La vitesse suivant EOF sera constante, que nous admettions ou non cette hypothèse, car la limite EOF est une ligne de hauteur piézométrique constante et égale à celle de la masse d'eau au repos à l'intérieur de la galerie, et non une ligne de pression constante. Nous négligeons l'influence de la viscosité du fluide.

Avant d'entreprendre cette analyse, il convient de disposer le plan physique (ou plan z) suivant le schéma de la figure $2 a$, dans laquelle, de même que dans la figure 1, les limites libres sont représentées en pointillé, et les limites solides par des traits pleins. En suivant le procédé classique [1] pour la représentation des problèmes de ce genre, nous employons également trois autres plans:

- Le plan du potentiel complexe $w=0+i \Psi$ (fig. $2 b$ );

- Un plan $\zeta$ intermédiaire, tel que la région d'écoulement s'inscrive dans la moitié supérieure de ce plan (fig. $2 c$ );

- Le plan de $\mathrm{T}=\log \mathrm{U} \frac{d z}{d w}=\log \frac{\mathrm{U}}{v}+i \theta$

(fig. $2 d$ );
U étant une vitesse-type quelconque (prise généralement sur un filet liquide libre), $\theta$ étant l'angle formé par le vecteur de la vitesse résultante et l'axé des abscisses, et $v$ étant la grandeur de la résultante de vitesse. Dans ce dernier plan, toutes les limites solides situées sur le plan $z$ et tous les filets liquides libres, s'inscrivent sous forme de droites.

Nous choisissons $\mathrm{U}=v_{1}$, la vitesse sur DHC. Puisque le champ d'écoulement est symétrique, de part et d'autre de la ligne $\mathrm{OH}$, nous pouvons situer $\mathrm{O}$ à l'origine des plans $z$ et $w$. Soit $v_{2}\left(<v_{1}\right)$ la vitesse suivant EOF, et soit $2 l$ la longueur de la courbe EOF; dans ces conditions, les abscisses des points $\mathrm{E}$ et $\mathrm{F}$ seront, sur le plan $w$, respectivement $-v_{2} l$, et $+v_{2} l$. Sur le plan $\zeta$, les abscisses de ces mêmes points sont $+b$ et $-b$; la grandeur de $b$ est encore inconnue, mais elle sera fonction de $v_{1}, v_{2}$, $a$, et $l$, $a$ étant la profondeur d'écoulement à une grande distance à l'amont ou à l'aval. Nous définissons $\varphi$ comme une valeur augmentant dans le sens de l'écoulement, soit : $v_{x}=+\partial \varphi / \partial x$, etc.

Sur le plan $\zeta$, le schéma d'ćcoulement comporte une source en $D, A$, et un puits en $C, B$, la valeur de l'écoulement, dans la moitié supérieure de ce plan, étant égale à $v_{1} a$. Ceci nous donne, pour l'équation $w-\zeta$ :

$$
w=\frac{v_{1} a}{\pi} \log \frac{\zeta-1}{\zeta+1}
$$

soit :

Au point $\mathrm{E}$ :

$$
\zeta=-\operatorname{cotgh} \frac{\pi u r}{2 v_{1} a}
$$

d'où :

$$
\zeta=+b, \quad w=-v_{2} l
$$

$$
b=\operatorname{cotgh} \frac{\pi v_{2} l}{2 v_{1} a}
$$


Sur le plan T, il est évident que les limites de l'écoulement se présentent sous la forme des limites d'un rectangle de largeur égale à $\mathrm{BF}=$ $\log \left(v_{1} / v_{2}\right)$, et de hauteur $\mathrm{BA}=2 \alpha$. Il s'ensuit que, d'après la transformation de SchwarzCristoffel :

$$
\begin{aligned}
\mathrm{T} & =\mathrm{G} \int \frac{d \zeta}{\sqrt{\left(\zeta^{2}-1\right)\left(\zeta^{2}-b^{2}\right)}}+\mathrm{L} \\
& =\frac{\mathrm{G}}{b} \mathrm{~F}(1 / b, \zeta)+\mathrm{L}
\end{aligned}
$$

dans laquelle $\mathrm{F}(1 / b, \zeta)$ désigne l'intégrale elliptique de première espèce, de module égal à $1 / b$. Afin de respecter la notation classique de ces intégrales, nous poserons $1 / b=k$. Il découle alors des conditions aux limites en $\mathrm{A}$ et en $\mathrm{B}$, que $\mathrm{L}=0, \mathrm{G}=-i \alpha / \mathrm{K} k, \mathrm{~K}$ étant l'intégrale elliptique complète, dont les limites sont 1 et 0 . D'où, à partir des équations (1) et (3), nous avons :

$$
\mathbf{T}=\log \frac{v_{1}}{v}+i \theta=\frac{i \alpha}{\mathrm{K}} \mathrm{F}\left(k, \operatorname{cotgh} \frac{\pi \omega}{2 v_{1} a}\right)
$$

$\mathrm{Et}$, à partir des conditions aux limites en $\mathrm{E}$, et du résultat bien connu :

$$
\mathrm{F}\left(k, \frac{1}{k}\right)=\mathrm{K}+i \mathrm{~K}^{\prime}
$$

$\mathrm{K}^{\prime}$ étant pris par rapport au module complémentaire $k^{\prime}=\sqrt{1--k^{2}}$, nous obtenons :

$$
\frac{v_{1}}{v_{2}}=e^{\mathrm{a} \mathrm{K}^{\prime} / \mathrm{K}}
$$

Examinons maintenant l'emploi de cette équation (5) pour l'exploration de régions présentant un intérêt particulier; dans tous les cas, l'on détermine d'abord les valeurs de $k$, à partir des tableaux (2), et ensuite, celles de $l / a$, et de $v_{1} / b_{2}$, à partir des équations (2) et (5). Ces régions particulières sont :

\section{La ligne de symétrie $\mathrm{OH}$.}

Cette ligne correspond à l'axe imaginaire des plans $w$ et $\zeta$ et à l'axe réel du plan T. La transformation bien connue :

$$
\mathrm{F}(k, i \eta)=i \mathrm{~F}\left(k^{\prime}, \eta / \sqrt{\left.1+\eta^{2}\right)}\right.
$$

et les équations (1) et (3) nous fournissent la relation :

$$
\mathrm{T}=\log \frac{p_{1}}{v}=\frac{\alpha}{\mathrm{K}} \mathrm{F}\left(k^{\prime}, \cos \frac{\pi \psi}{2 v_{1} \alpha}\right)
$$

Cette équation en $v--\psi$ permet, par tabulation numérique, et à l'aide de l'équation

$$
\Delta y=\Delta \psi / v \text {, }
$$

d'obtenir une relation en $v-l y$, et de là, de déterminer la répartition des pressions suivant $\mathrm{OH}$, la poussée globale $\mathrm{F}$, le moment de flexion
M par rapport à $O$, et la distance $\bar{y}$, entre le centre de poussée et le point $O$. Les mesures adimensionnelles de ces quantités :

$$
\mathrm{F}^{\prime}=\frac{\mathrm{F}}{\mathrm{I}_{1} \rho v_{1}{ }^{2} a}, \quad \mathrm{M}^{\prime}=\frac{\mathrm{M}}{\frac{1}{2} \rho v_{1}{ }^{2} a^{2}}, \quad \ddot{y}^{\prime}=\frac{\bar{y}}{a}=\frac{\mathrm{M}^{\prime}}{\mathrm{F}^{\prime}}
$$

sont portées, sur la figure 3 en fonction du rapport $a / d$, pour plusieurs valeurs de $\alpha$. Cette même tabulation fournit des valeurs de $y_{0} / a$ (fig. 1), lesquelles sont portées en fonction de $a / d$, sur la figure 4 ; le rapport des hauteurs $\mathbf{H}_{1} / \mathbf{H}_{0}$ (fig. 1 ), égal à $1-\left(v_{2} / v_{1}\right)^{2}$, est représenté, arec $v_{2} / v_{1}$, en fonction de $a / d$, sur la figure 5 .

\section{La ligne EOF.}

Suivant cette ligne, $\zeta$ est une valeur réelle, et plus grande que $1 / k ; w$ est une valeur réelle, égale à $v_{2} s, s$ étant la distance le long du filet liquide, mesurée à partir du point $O$. Les équations (1), (3), et la transformation classique :

pour

$$
\mathrm{F}(k, x)=i \mathrm{~K}^{\prime}+\mathrm{F}\left(k, \frac{1}{k x}\right)
$$

$$
x>1 / k
$$

nous donnent, pour $w / v_{2} l=s / l=\varphi^{\prime}$ :

$$
\mathrm{T}=\log \frac{b_{1}}{b_{2}}+\frac{i x}{\mathrm{~K}} \mathrm{~F}\left\{k, \frac{1}{k} \operatorname{tgh}\left(\varphi^{\prime} \operatorname{tgh}^{-1} k\right)\right\}
$$

d'où :

$$
\frac{\theta}{\alpha}=\frac{1}{\mathrm{~K}} \mathrm{~F}\left\{k, \frac{1}{k} \operatorname{tgh}\left(\varphi^{\prime} \operatorname{tgh}^{-1} k\right)\right\}
$$

Cette équation fournit une relation en $s-\theta$, pour la courbe EOF, laqquelle permet de déterminer, par tabulation numérique, une relation en $x-y$. Il en résulte la profondeur du pertuis (fig. 2) qui est donnée par :

$$
d=2 x_{m} \sin x
$$

et, de là, la valeur du rapport $a / d$, laquelle intervient dans les figures 3 , 4 , et 5 , en tant que variable indépendante, et supposée connue d'avance. La longueur $h$ (fig. 1) se détermine aisément d'après la géométrie de la courbe, et à partir de $y_{0}$; la figure 4 montre les valeurs du rapport $h / d$, en fonction de celles du rapport $a / d$.

En tirant les dérivées, à partir de l'équation (9), nous déterminons le rayon de courbure $r$ pour n'importe quel point sur EOF :

$$
\begin{aligned}
r=\frac{a}{\alpha} \frac{2 \mathrm{~K} k}{\pi} & e^{\sigma \mathrm{K} \mathrm{K}^{\prime} / \mathrm{K}} \cosh \left(\varphi^{\prime} \operatorname{tgh}^{-1} k\right) \times \\
& \times \sqrt{1-\frac{1}{k^{2}} \operatorname{tgh}^{2}\left(\varphi^{\prime} \operatorname{tgh}^{-1} k\right)}
\end{aligned}
$$

Au point $\mathrm{O}, \varphi^{\prime}=0$, et :

$$
r=r_{2}=\frac{\alpha}{s} \frac{2 \mathrm{~K} k}{\pi} e^{\alpha \mathrm{K}^{\prime} / \mathrm{K}}
$$

Les valeurs de $k$, correspondant aux faibles valeurs du rapport $a / d(<1)$, normalement ren- 
contrées dans le domaine pratique, sont très voisines de l'unité, de sorte qu'il est évident, d'après l'équation (11), qu'à l'intérieur d'une large bande dans la partie centrale de la courbe EOF, la valeur de $r$ est très voisine de celle de $r_{2}$.

\section{La ligne DHC.}

Suivant cette ligne, la valeur de $\zeta$ est réelle, et numériquement inférieure à l'unité; celle de $T$ est purement imaginaire. Soit $s$ la distance mesurée le long du filet liquide, à partir de $\mathrm{H}$, et soit $s^{\prime}=s / a$; il s'ensuit que, puisque

$$
\begin{gathered}
\downarrow=v_{1} a: \\
w=v_{1} a\left(s^{\prime}+i\right)
\end{gathered}
$$

d'où à partir des équations (1) et (3) :

$$
\frac{\theta}{\alpha}=\frac{\mathrm{F}\left[k, \operatorname{tgh}\left(\pi s^{\prime} / 2\right)\right]}{\mathrm{K}}
$$

En tirant les dérivées de cette équation, nous obtenons, pour le rayon de courbure $r$, la relation :

$$
r=\frac{a 2 \mathrm{~K}}{\alpha \pi} \cosh \frac{\pi s^{\prime}}{2} \sqrt{1-k^{2} \operatorname{tgh}^{2}\left(\pi s^{\prime} / 2\right)}
$$

Au point $\mathrm{H}, \boldsymbol{s}^{\prime}=0$, et :

$$
r=r_{1}=(a / \alpha)(2 \mathrm{~K} / \pi)
$$

De même que sur la ligne EOF, le voisinage de la valeur $k$ avec l'unité, sur cette courbe, signifie qu'il existe, dans la partie centrale de celle-ci, une large bande à l'intérieur de laquelle la valeur de $r$ reste, à la fois sensiblement constante et égale à celle de $r_{1}$.

\section{L'approximation du vortex libre.}

Lorsque la valeur de $k$ est très voisine de l'unité, il se présente également une approximation intéressante. D'après les équations (12), et (15), nous avons :

$$
\frac{r_{2}}{r_{1}}=k e^{\alpha \mathrm{K}^{\prime} / \mathrm{K}}=k \frac{\partial_{1}}{v_{2}}
$$

suivant l'équation (5), d'où :

$$
\frac{r_{2} v_{2}}{r_{1} v_{1}}=k
$$

et, lorsque la valeur de $k$ est très voisine de l'unité, celle du produit or reste sensiblement constante sur toute la longueur de la ligne $\mathrm{OH}$, comme dans le cas de vortex libre. Dans ces conditions, connaissant auparavant, soit $r_{1}$, soit $r_{2}$, l'exploration du schéma d'écoulement devient chose facile. Connaissant $r_{1}$, nous obtenons $r_{2}$ en calculant le débit s'écoulant à travers la ligne $\mathrm{OH}$, lequel est égal à :

$$
v_{1} a=\int_{r_{1}}^{r_{2}} v d r=\int_{r_{1}}^{r_{2}} \frac{v_{1} r_{1}}{r^{r}} d r=v_{1} r_{1} \log \frac{r_{2}}{r_{1}}
$$

$$
r_{2}=r_{1} e^{a / r_{1}}
$$

Nous obtenons alors, par l'intégration du coefficient de pression $p^{\prime}=1-\left(v / v_{1}\right)^{2}$, à travers $\mathrm{OH}$ :

$$
\mathbf{F}^{\prime}=\frac{\mathbf{F}}{{ }^{\frac{1}{2}} \rho v_{1}{ }^{2} a}=\frac{\left(r_{2}-r_{1}\right)^{2}}{a r_{2}}
$$

et, en intégrant le moment de cette pression par rapport au point $O$, nous obtenons :

$$
\mathrm{M}^{\prime}=\frac{\mathrm{M}}{\frac{1}{2} \rho v_{1}^{2} a^{2}}=\frac{\left(r_{2}-r_{1}\right)\left(r_{2}-3 r_{1}\right)+2 r_{1} a}{2 a^{2}}
$$

et, de là :

$$
\ddot{y}^{\prime}=\frac{\mathrm{M}^{\prime}}{\mathrm{F}^{\prime}}=\frac{r_{2}\left(r_{2}-3 r_{1}\right)}{2 a\left(r_{2}-r_{1}\right)}+\frac{r_{1} r_{2}}{\left(r_{2}-r_{1}\right)^{2}}
$$

Les équations $(18,19,20)$ sont représentées par les lignes brisées de la figure 3 , et montrent que l'approximation du vortex libre s'accorde assez bien avec la théorie complète, lorsque la valeur du rapport $a / d$ est inférieure à environ 0,8 .

Cette approximation ne peut toutefois suffire entièrement à elle seule, car l'appel à la théorie complète reste nécessaire pour déterminer la valeur initiale de $r_{1}$, ou bien celle de $r_{2}$. Mais, dans le cas du «pied de déversoir solide », lor'sque EOF représente une limite solide dont le rayon est connu, il semble que la théorie du vortex libre puisse s'appliquer directement. Nous verrons, dans une deuxième étude, à quel point, et à quelle précision près, cette théorie est valable pour le cas précité.

\section{Paramètres de calcul, et application des résultats.}

Des résultats numériques sont donnés, dans les figures 3,4 , et 5 , pour quatre valeurs différentes de l'angle de déflexion total $2 \alpha$ du jet: - $35^{\circ}, 40^{\circ}, 45^{\circ}$, et $90^{\circ}$. Cette dernière valeur de l'angle correspond à un déversoir en saut de ski. Malgré le fait qu'il est très peu probable qu'un tel déversoir soit réalisé avec une galerie ouverte, nous en avons néanmoins tenu compte, afin de permettre la comparaison avec le cas du «pied de déversoir solide», que nous examinerons dans notre deuxième étude.

Nous avons déjà vu que la valeur de $k$ est généralement voisine de l'unité. Or, $k \rightarrow 1$ lorsque $a / d \rightarrow 0$, et, dans la pratique, la valeur du rapport $a / d$ dépasse rarement 0,6 , ce qui correspond à $k=\sin 84^{\circ}=0,995$, pour $2 \alpha=45^{\circ}$. Des résultats sont indiqués, pour les valeurs du rapport $a / d$ allant jusqu'à l'unité, laquelle risque rarement d'être dépassée dans la pratique. Mais, même pour cette valeur, $k=0,927$, lorsque $2 \alpha=45^{\circ}$

Nous aurions d'ailleurs pu, dans une certaine mesure, éviter d'avoir recours aux transformations $(6,8)$ pour les valeurs imaginaires et complexes si nous avions pris les valeurs tabulées, 
et données par les graphiques de la référence bibliographique [3].

Les données énumérées ci-après devraient, en principe, fournir les indications nécessaires pour le calcul des armatures des parois latérales :

1. Les positions des points $O$ et $H$, qui sont données par les valeurs des rapports $h / d$ et $y_{0} / \alpha$ (fig. 4).

2. La répartition des pressions, et le moment de flexion, suivant $\mathrm{OH}$, donnés par la figure 3 , et supposés intéresser une bande, de largeur unitaire, suivant $\mathrm{OH}$.

3. La pression hydrostatique, dans la région située au-dessous de la limite EOF, donnée par la figure 5.

4. Les éléments nécessaires pour tracer les courbes EOF et DHC. Puisque la valeur de $k$ est si voisine de l'unité, nous pouvons représenter ces courbes, en bonne approximation, sous la forme d'arcs de cercle, passant par les points $O$ et $H$, et étant tangents, à la fois, aux limites $\mathrm{AE}, \mathrm{FB}$, et aux plans d'eau amont et aval.

Les forces et les moments donnés par la figure 3 , sont engendrés uniquement par la diminution de la vitesse suivant $H O$, et doivent être ajoutés à ceux engendrés par la pression hydro- statique due à la profondeur à laquelle est situé le point $O$, au-dessous du point $H$. La figure 6 montre comment la poussée dynamique donnée par la figure 3 et représentée par la région MNH, s'ajoute à la poussée hydrostatique, représentée par HON et par OMPL.

La mesure des hauteurs $H_{1}$ et $H_{0}$ doit se faire à partir d'un point quelconque, de pression nulle, e'est-à-dire situé sur la surface libre DHC. Logiquement, le choix d'un point médian (correspondant à une vitesse moyenne) doit se porter sur le point $H$; dans la figure 5 , les points $H_{1}$ et $H_{0}$ sont tracés en fonction d'un niveau de base ainsi choisi. La connaissance du point $\mathrm{H}_{0}$ permet de déterminer $b_{1}$, et de là, la valeur de $a$. Nous verrons, dans la partie de la présente étude traitant des résultats expérimentaux, comment il est possible de tenir compte des pertes d'énergie sur la surface du déversoir.

Les figures 3 , 4 , et 5 présentent également des valeurs pour $a / d=\infty$, c'est-à-dire pour le cas d'un angle brusque au pied du déversoir. Dans ce cas, $k=0$, l'intégrale elliptique dégénère en une fonction de sinus inverse. La solution du problème représente un cas particulier de l'équation (6):

$$
\mathrm{T}=\log \frac{v_{1}}{v}+i \theta=\frac{2 i z}{\pi} \sin ^{-1}\left(\operatorname{cotgh} \frac{\pi \omega}{2 v_{1} a}\right)
$$

\section{3. - VANNE DE GALERIE OUVERTE}

\section{Solution théorique.}

Nous étudierons le cas dans lequel la vanne de la galerie est ouverte, de sorte que l'eau s'écoule, à la fois, par la galerie et sur la face du déversoir. C'est ce qui pourrait se passer pendant Ia vidange exceptionnelle de la retenue. Dans ces conditions, l'on recherche, en particulier, les réponses aux questions suivantes :

1. Le moment de flexion intéressant les pàrois latérales est-il plus grand ou plus petit que lorsque la vanne de la galerie est fermée?

2. Dans quelle mesure l'écoulement sur la face du déversoir provoque-t-il la réduction de l'écoulement par la galerie?

Le schéma de ces écoulements est représenté par la figure $7 a$. Afin qu'une solution soit possible, nous devons admettre non seulement que la viscosité de l'eau est négligeable, mais encore que les deux courants présentent les mêmes énergies totales. Cette hypothèse paraît valable dans la pratique; en effet, les deux courants possèdent, au départ, les mêmes quantités d'énergie, et doivent sans doute, tous les deux, subir des pertes du même ordre, en s'écoulant vers le pied du déversoir.

Le point $\mathbf{E}$ constitue, à la fois, l'origine d'un filet liquide séparant les deux courants, et un point de stagnation commun pour ceux-ci; en effel, s'il ne l'était que pour un seul courant, il y aurait une discontinuité de pression. Le filet liquide passant par $\mathrm{E}$ n'est donc tangent, ni à $\mathrm{AE}$, ni à DE.

De même que dans l'analyse précédente, nous avons négligé l'influence de la pesanteur; la vitesse suivant le filet liquide libre $\mathrm{AB}$ est égale à $v_{1}$, et celle dans la galerie à $v_{2}$. Nous retenons également la définition précédente pour les longueurs $a$ et $d$, mais il conviendra mieux, cette fois, de définir l'axe $\mathrm{X}$ comme étant parallèle à DB. Les débits par unité de largeur correspondant aux deux courants, sont $Q_{1}=v_{1} a$ sur la face du déversoir, et $\mathrm{Q}_{2}=v_{2} d$, dans la galerie.

La figure $7 b$ montre le plan $\zeta$ intermédiaire, le point $B$ étant l'infini, et les points $A$ et $D$ étant disposés symmétriquement par rapport à 
l'origine. Les longueurs $b$ et $c$ sont encore inconnues. La figure $7 c$ montre le plan correspondant a $\mathrm{T}=\log \left(v_{1} / v\right)+i$. Les limites solides sont représentées en traits pleins, et les limites libres en pointillé.

Dans le plan $\zeta$, le schéma d'écoulement présente une source, de puissance $2 Q_{1}$, en $A$, et une deuxième source, de puissance $2 Q_{2}$, en $D$. L'équation en $w-\zeta$ se présente ainsi :

$$
w=\frac{Q_{1}}{\pi} \log (\zeta+b)+\frac{Q_{2}}{\pi} \log (\zeta-b)
$$

d'où :

$$
\frac{d w}{d \zeta}=\frac{Q_{1}}{\pi(\zeta+b)}+\frac{Q_{2}}{\pi(\zeta-b)}
$$

Au point $\mathrm{E}, d w / d \zeta=0$, de sorte que :

$$
\frac{c}{b}=\frac{Q_{1}-Q_{2}}{Q_{1}+Q_{2}}
$$

Le théorème de Schwarz-Cristoffel nous donne, pour la relation en $\mathrm{T}-\zeta$ :

$$
\begin{aligned}
\mathrm{T} & =\mathrm{G} \int \frac{d \zeta}{(\zeta-c) \sqrt{\zeta+b}}+\mathrm{L} \\
& =2 \mathrm{Gtgh}^{-1} \sqrt{\frac{\zeta+b}{b+c}}+\mathrm{L}
\end{aligned}
$$

Les conditions aux limites en $A$, et en $B$, montrent que $\mathrm{L}=-2 i \alpha, \mathrm{G}=2 \alpha / \pi$, d'où :

$$
\mathrm{T}=\frac{4 \alpha}{\pi} \operatorname{tgh}^{-1} \sqrt{\frac{\zeta+b}{b+c}}-2 i \alpha
$$

Au point $\mathrm{D}, v=v_{2}$, et $\lambda=+b$. Il s'ensuit que, d'après l'équation (25):

$$
\sqrt{\frac{2 b}{b+c}}=\frac{1+\left(v_{1} / v_{2}\right)^{\pi / 2 \pi}}{1-\left(v_{1} / v_{2}\right)^{\pi / 2 \alpha}}
$$

En introduisant, pour $c / b$, la valeur donnée par l'équation (23), et en remaniant l'expression, nous obtenons la relation :

$$
\mathrm{Q}_{1} / \mathrm{Q}_{2}=\frac{1^{*}}{4}\left\{\left(v_{1} / v_{2}\right)^{\pi / 4 \alpha}-\left(v_{2} / v_{1}\right)^{\pi / 4 \alpha}\right\}^{2}
$$

et, puisque $\mathrm{Q}_{1} / \mathrm{Q}_{2}=v_{1} a / v_{2} d$, l'équation (26) fournira $a / d$ comme fonction de $v_{1} / v_{2}$, et $\mathrm{Q}_{1} / \mathrm{Q}_{2}$ comme fonction de $a / d$.

\section{Réduction de l'écoulement dans la galerie.}

Soit $\mathrm{Q}_{0}$ le débit qui s'écoulerait par la galerie s'il n'y avait aucun écoulement sur la face du déversoir. Dans ce cas, la vitesse dans la galerie serait égale à $v_{1}$, de sorte que $\mathrm{Q}_{0}=v_{1} d$. Il est intéressant de se rendre compte si la somme $\left(Q_{1}+Q_{2}\right)$ est supérieure ou inférieure à $Q_{0}$; si elle était inférieure, le débit total se trouverait réduit par l'écoulement sur le déversoir. Nous considérerons le cas-type $\alpha=\pi / 8$, soit $\pi / 4 \alpha=2$. Or, d'après l'équation (26), nous avons :

$$
\begin{aligned}
\frac{\mathrm{Q}_{1}+\mathrm{Q}_{2}}{\mathrm{Q}_{0}}= & \frac{v_{1} a+v_{2} d}{v_{1} d}=\frac{a}{d}+\frac{v_{2}}{v_{1}}=\frac{v_{2}}{v_{1}}\left(1+\frac{\mathrm{Q}_{1}}{\mathrm{Q}_{2}}\right) \\
& =\frac{1}{4} \frac{v_{2}}{v_{1}}\left\{\left(\frac{v_{1}}{v_{2}}\right)^{2}+\left(\frac{v_{2}}{v_{1}}\right)^{2}\right\}^{2}
\end{aligned}
$$

On démontre aisément que la valeur de cette expression est minimale, et égale à 0,940 , lorsque $v_{2} / v_{1}=0,880$, soit $a / d=0,060$. En fait, cette valeur reste inférieure à l'unité, tant que $0,77<v_{2} / v_{1}<1$, soit $0<a / d<0,23$. (Notons que, lorsque $\mathrm{Q}_{1} \rightarrow 0, v_{2} / v_{1} \rightarrow 1$, et $a / d \rightarrow 0$. Pour $\left.\mathrm{Q}_{1}>0, v_{2} / v_{1}<1\right)$.

La conclusion est intéressante : il existe donc une gamme de valeurs du rapport $a / d$, pour laquelle $Q_{1}+Q_{2}>Q_{0}$, c'est-à-dire que le débit passant par le déversoir entrave et réduit le débit en galerie, d'une quantité supérieure au débit du déversoir lui-mềme. Cette tendance générale est mise en évidence sur la figure 8 , par les courbes correspondant à $Q_{1} / Q_{2}$ et à $\left(Q_{1}+Q_{2}\right) / Q_{0}$, en fonction de $a / d$, pour $2 \alpha=35^{\circ}, 40^{\circ}, 45^{\circ}$.

Considérons maintenant cette conclusion à la lumière de l'emploi de la galerie comme organe de vidange exceptionnelle du réservoir. Le fonctionnement du déversoir n'augmentera le débit total que lorsque la valeur moyenne de $a / d$ sera supérieure d̀ 0,2 (fig. 8). Puisque $a \cong Q_{1}$, cette condition ne sera atteinte que lorsque la valeur de $Q_{\mathrm{L}}$ sera assez importante, et lorsque le plan d'eau dans la retenue se trouvera à une cote suffisamment élevée; dès que le plan d'eau retombera au-dessous de ladite cote, la contribution du déversoir sera nulle.

La conclusion à tirer de ce qui précède est que le fonctionnement du déservoir augmente le débit de l'ordre de $20 \%$ (fig. 8), pendant une faible partie seulement (quelques pour cent) de la vidange de la retenue. Le fonctionnement du déversoir ne permet donc de réduire que d'un très faible pourcentage le temps nécessaire à la vidange complète de la retenue. Dans un des cas examinés par l'auteur, cette marge était seulement de l'ordre de $3 \%$.

\section{Répartition des pressions et des vitesses.}

L'analyse a conduit à des relations simples entre les rapports des débits et le rapport $a / d$. Par contre, explorer la répartition des vitesses et des pressions au voisinage de l'ouverture du pertuis, se révèle beaucoup plus difficile, puisque, cette fois, LH ne représente plus un axe de symétrie. Pour explorer la région $\mathrm{LH}$, il est nécessaire de tracer l'équipotentielle $\mathrm{EF}$, ensuite le filet d'écoulement $\mathrm{FG}$, et enfin, des équipotentielles type GK, jusqu'à la surface libre (fig. 7). 
Cette représentation graphique se réalise par la résolution numérique des équations $(22,23$, 25) pour les incréments $\Delta s=\Delta \varphi / v$ et $\Delta n=\Delta \downarrow / \nu$. Des calculs, effectués pour le cas $\alpha=\pi / 8$, $\mathrm{Q}_{1}=\mathrm{Q}_{2}$, d'où $a / d=0,644$, ont montré que le moment de flexion, au voisinage de $\mathrm{LH}$, était plus que deux fois plus grand que dans le cas de la galerie fermée. Pour cette raison, et puisque le fonctionnement en galerie ouverte ne présente qu'un si faible avantage, quant à l'augmentation du débit, ce mode de fonctionnement n'est guère à conseiller; par conséquent, aucun examen complet de la répartition des pressions ne sera entrepris dans la présente étude.
Nous indiquerons, par contre, dans un chapitre ultérieur, des valeurs expérimentales pour la hauteur $h$; les valeurs du rapport des hauteurs de charge $\mathrm{H} /\left(\mathrm{H}_{1}+h\right)$ intéressant le radier sont données par la courbe de la figure $7 a$, pour $\alpha=\pi / 8, \quad a / d=0,644$. Ces données permettent, dans n'importe quel cas particulier, de tracer au moins les grandes lignes du schéma d'écoulement et de la répartition des pressions, en déduisant la pression à l'intérieur de la galerie à partir de la valeur de $Q_{1} / Q_{2}$ (fig. 8), et en admettant que la répartition des pressions sur le radier ait à peu près la forme représentée sur la figure $7 a$.

\section{4. - RESULTATS EXPERIMENTAUX}

Des essais ont été effectués dans un canal de 6 pouces de large $(152,4 \mathrm{~mm})$ et comportant des parois en matière plastique transparente. Un modèle de déversoir, ayant une hauteur totale de $11^{\prime \prime} 3 / 8(289 \mathrm{~mm})$, et dont la face présentait une inclinaison de $45^{\circ}$ par rapport à l'horizontale, a été installé dans le canal. Le pied du déversoir était calé à une hauteur $d$ au-dessus du radier du canal, de manière à constituer une galerie sous le déversoir proprement dit. Les hauteurs $d$ du pertuis ont été réglées, successivement, à $1,25,2,3$, et 4 pouces $(31,75,50,8$, 76,2 et $101,6 \mathrm{~mm}$ ); deux séries d'essais ont été effectuées pour chaque hauteur, dont l'une avec la galerie obturée et l'autre avec la galerie ouverte, de sorte que l'eau s'écoulait à la fois sur le déversoir et par la galerie.

\section{Résultats des essais avec la galerie obturée. Essais de l'auteur.}

Les mesures effectuées pendant chaque essai ont porté sur le débit (par la méthode volumétrique), sur le niveau de l'eau à l'amont du déversoir, la hauteur d'eau $h$ (fig. 1), et la valeur de la pression à l'intérieur de la galerie. Cette dernière mesure a été effectuée au moyen d'un manomètre relié à un point situé à l'intérieur de la galerie, à l'abri de tout perturbation locale provoquée par la contrainte de cisaillement suivant la surface EOF. La détermination de $\mathrm{H}_{1}$ et de $\mathrm{H}_{2}$ s'est effectuée sans difficulté, à partir des résultats de ces mesures, la valeurs de $a$ étant alors obtenue à partir de la relation :

$$
a=\mathrm{Q} / b v_{1}=\mathrm{Q} / b \sqrt{2 g \mathrm{H}_{0}}
$$

$b$ étant la largeur du canal. Nous n'avons tenu compte, ni de la perte d'énergie sur la face du déversoir, ni des «panaches» caractéristiques qui se sont formés sur les parois latérales; en effet, puisque ces panaches sont, sans doute, soumis, à peu de choses près, à la pression atmosphérique, ils ne contribuent en rien à la poussée à laquelle sont soumises ces parois. Nous reparlerons de la perte d'énergie plus loin.

Les valeurs expérimentales, obtenues pour $h / s$ en fonction de $a / d$, sont portées sur la courbe de la figure 4. Pour la galerie obturée, ces valeurs s'accordent assez bien avec les valeurs théoriques, lorsque $a / d>0,4$; au-dessous de cette valeur, les points expérimentaux tendent à s'approcher de l'origine de la courbe, sans doute parce que, dans cette région, les hypothèses admises pour l'analyse ne sont plus valables, puisque la galerie n'est plus entièrement remplie d'eau.

Les valeurs expérimentales de $\mathbf{H}_{1} / \mathbf{H}_{0}$ sont portées en fonction de $a / d$ sur la figure 5 . Pour les galeries de 1,25 et 2 pouces, (31,75 et $50,8 \mathrm{~mm}$ ), elles s'accordent bien avec les données théoriques, mais moins bien dans le cas des galeries de 3 et 4 pouces, (76,2 et $101,6 \mathrm{~mm})$ peut-être parce que l'hypothèse d'une vitesse constante suivant la surface libre supérieure représente, à peu de choses près, la réalité, lorsque les valcurs du rapport $d / \mathrm{H}_{0}$ sont peu élevées, alors que pour des plus grandes valeurs de ce même rapport, l'influence de la gravité entraîne des variations appréciables de la vitesse $v_{1}$ dans la zone située au voisinage du débouché de la galerie; dans ces conditions, le choix d'un niveau de référence pour la mesure de $\mathrm{H}_{1}$, et de $\mathrm{H}_{0}$ devient incertain.

En particulier, le choix du point $H$ est plutôt 
aléatoire, mais il est possible, dans une grande mesure, de compenser les erreurs dues à cette incertitude en tenant compte de la manière dont se comporte la somme $\left(\mathrm{H}_{1}+h\right)$. Cette somme peut être déterminée pour toute valeur de $d$; le tableau ci-dessous résume les valeurs correspondant au cas-type, avec

$$
d=3^{\prime \prime}(76,2 \mathrm{~mm}) \text {. }
$$

Valeurs de $\left(\mathrm{H}_{1}+h\right)$, en pieds, pour $d=3^{\prime \prime}$ $(76,2 \mathrm{~mm})$ :

\begin{tabular}{|c|c|c|}
\hline \multicolumn{2}{|c|}{$\mathbf{H}_{1}+h$} & \\
\hline \multirow{2}{*}{ théórique } & expérimental & $a / d$ \\
& & \\
\cline { 3 - 3 } & & \\
\hline 0,161 & 0,187 & 0,094 \\
0,230 & 0,255 & 0,160 \\
0,304 & 0,325 & 0,231 \\
0,415 & 0,440 & 0,344 \\
0,534 & 0,565 & 0,464 \\
0,648 & 0,665 & 0,580 \\
0,768 & 0,774 & 0,711 \\
0,854 & 0,860 & 0,810 \\
0,928 & 0,934 & 0,906 \\
& & \\
\hline
\end{tabular}

Même aux plus faibles valeurs du rapport $a / d$, la théorie et l'expérience s'accordent mieux que dans les cas de $\mathrm{H}_{1} / \mathrm{H}_{0}$ ou de $h_{1} / d$, ce qui permet de penser que des erreurs de signes contraires ont dû s'annuler. Cette concordance est précise à $5 \%$ près, et convient donc parfaitement bien pour les calculs, tant que $a / d>0,3$; cette dernière valeur est généralement dépassée lorsque le débit est maximal, c'est-à-dire dans la condition critique pour le calcul.

Les valeurs correspondantes, pour d'autres valeurs de $d$, s'accordent encore mieux, lorsque $d<3$ pouces, $(76,2 \mathrm{~mm})$, mais moins bien lorsque $d=4$ pouces, $(101,6 \mathrm{~mm})$. Ceci nous permet de conclure, également, que la concordance doit être bonne pour $d / H_{0} \leqslant 0,2$, environ.

Il importe cependant de souligner que la tabulation précédente n'est valable que pour une seule disposition expérimentale; il n'est guère possible d'établir une solution adimensionnelle générale pour $\left(H_{1}+h\right)$, puisque $H_{1}$ est liée à $H_{0}$, $h$ à $d$, et puisque le rapport $d / \mathrm{H}_{0}$, est variable.

\section{Résultats obtenus avec la galerie fermée. Essäis relatifs à l'aménagement hydroélectri- que de Roxburgh.}

Il reste à déterminer comment la pression est sensible à la distorsion au voisinage de la ligne EOF, soit sous l'influence de la contrainte de cisaillement, soit sous celle de forces de gravité locales. Nous examinerons à cette fin des essais effectués par le Ministère des Travaux de la Nou. velle-Zélande, comprenant des études sur modèle de l'évacuateur de crues de l'aménagement hydroélectrique de Roxburgh. La pente de ce déversoir est de $45^{\circ}$, comme celle considérée dans les essais précédents; en fait, des points correspondant à ces derniers sont compris dans les abaques des figures 4 et 5 .

Les essais eflectués pour le compte de Roxburgh ont compris l'exploration très poussée des pressions aux parois latérales du déversoir; les résultats obtenus ont permis, dans une grande mesure, d'élucider le schéma d'ensemble des phénomènes. La figure 9 montre les profils d'écoulement et la répartition des pressions, obtenus pour $a / d=0,57$, ainsi que la répartition théorique des pressions. A l'intérieur du pertuis, les deux répartitions coïncident presque, mais à l'aval de la ligne de symétrie $\mathrm{LOH}$, on constate l'existence d'une concentration bien définie des pressions; celle-ci ne ressort guère de la théorie, mais elle est, sans aucun doute, provoquée par l'accélération du jet causée par la gravité et donnant aussi naissance à des vitesses et à des pressions centripètes plus élevées à l'aval de la ligne $\mathrm{LOH}$.

I'existence de ce «bulbe» de pression ne rend pas nécessairement la théorie moins utile pour le calcul des ouvrages. C'est le moment de flexion, dans certaines régions essentielles, telle que la ligne LOH, qui importe avant tout; la vérification la plus rigoureuse de cette théorie consiste à voir si elle permet de prévoir le moment de flexion avec une suffisante précision. Nous pouvons trancher cette question en tracant la répartition de pression suivant $\mathrm{LOH}$, mesurée et calculée, ainsi que nous lavons fait, à l'échelle, dans la figure 6, dont l'utilité a déjà été signalée en ce qui concerne l'emploi de $\mathbf{M}^{\prime}$, $F^{\prime}$, etc.

La figure 9 représente le même cas que le schéma de la figure 6 , Les dimensions de l'ouvrage réel sont: $d=30$ pieds, $(9 \mathrm{~m}), b=31$ pieds $(9,5 \mathrm{~m})$; (valeur moyenne; en effet, les parois latérales de la passe ne sont pas tout à fait parallèles), cote du plan d'eau de la retenue 170,1 pieds $(52 \mathrm{~m})$, au-dessus du radier, débit $\mathrm{Q}=51000$ pieds-cubes $/ \mathrm{s}\left(1444 \mathrm{~m}^{3} / \mathrm{s}\right)$. Il s'ensuit de ces données que $a=17,1$ pieds $(5,20 \mathrm{~m})$, $h=26,1$ pieds $(8 \mathrm{~m})$, grandeur détermince par tâtonnements, à parlir de l'équation (28), et de la figure 4 , et $a / d=0,57$. D'après les figures 4 et $5, \mathrm{H}_{1}=40$ pieds $(12,2 \mathrm{ml})$, et $y_{0}=18,55$ pieds, $(5,75 \mathrm{~m})$. D'apres la figure $3, \mathrm{~F}^{\prime \prime}=0,162$, et $\bar{y}=0,379$. Ces valeurs permettent de construire le profil des pressions de la ligure 6; la ressemblance des deux profils est remarquable. 
ESSAIS DU 《Ministry of Works》-AMÉNagement de RoxbuRgh

\begin{tabular}{|c|c|c|c|c|c|c|}
\hline \multirow{2}{*}{$\begin{array}{c}Q \\
\text { (pieds-cubes/s) }\end{array}$} & \multirow{2}{*}{$\frac{a}{d}$} & \multicolumn{2}{|c|}{$\left(\mathrm{H}_{1}+h\right)$ (pieds) } & \multicolumn{3}{|c|}{$\begin{array}{l}\text { Moment de flexion suivant } L O H, \\
\text { par rapport à } L \text { (pieds-cubes) }\end{array}$} \\
\hline & & théorique & expérimentale & théorique & expérimentale & écart \% \\
\hline 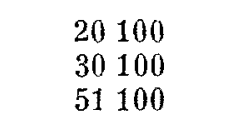 & $\begin{array}{l}0,230 \\
0,326 \\
0,570\end{array}$ & $\begin{array}{l}31,9 \\
44,2 \\
66,1\end{array}$ & $\begin{array}{l}31,5 \\
42,3 \\
63,6\end{array}$ & $\begin{array}{r}2080 \\
3862 \\
11815\end{array}$ & $\begin{array}{r}2270 \\
4170 \\
12340\end{array}$ & $\begin{array}{l}+9,1 \\
+7,8 \\
+4,4\end{array}$ \\
\hline 51100 & ient $c$ & on par ra & ort à $S$, suiva & $\mathrm{S}=$ & 9340 & \\
\hline
\end{tabular}

Le tableau ci-dessus résume les résultats, pour le cas considéré, ainsi que pour les deux autres cas $\left(Q=20100\right.$ pieds-cubes $/ \mathrm{s},\left(569 \mathrm{ml}^{3} / \mathrm{s}\right)$ et $Q=30100$ pieds-cubes $/ \mathrm{s}\left(852 \mathrm{~m}^{3} / \mathrm{s}\right)$. Les pressions sont exprimées en pieds de hauteur d'eau, et les moments de flexion en pieds-cubes, c'est-à-dire compte non tenu du poids spécifique $\gamma$.

Les valeurs théoriques s'accordent remarquablement bien avec les valeurs expérimentales, pour $Q=51100$ pieds-cubes $/ \mathrm{s}, \quad\left(1446 \mathrm{~m}^{3} / \mathrm{s}\right)$ mais moins bien aux débits moindres, car les courbes d'égale pression (qui ne sont pas représentées ici) montrent que, lorsque le débit décroît, le «bulbe» de pression remonte vers l'amont, et se centre en $\mathrm{L}$ jusqu'à $\mathrm{Q}=20000$ pieds-cubes $/ \mathrm{s} \quad\left(566 \mathrm{~m}^{3} / \mathrm{s}\right) \quad(\alpha / d=0,23)$. Le tableau montre que, pour un débit de 51100 piedscubes $/ \mathrm{s}$, (1 $\left.444 \mathrm{~m}^{3} / \mathrm{s}\right)$, la valeur du moment de flexion suivant $R S$, c'est-à-dire passant par le centre du «bulbe», est plus grande que ne l'indique la théorie; par contre, elle reste bien plus faible qu'elle ne l'est suivant la ligne $O H$.

Mais, même aux débits moindres, les valeurs s'accordent encore assez bien entre elles, car celle de $h$ est de beaucoup plus faible que ne l'indique la théorie. La force de gravité intervient, non seulement en donnant naissance au «bulbe » de pression localisé, représenté sur la figure 9, mais encore en rabattant le filet d'écoulement inférieur EOF. Ces deux phénomènes tendent à s'annuler, ce qui explique la bonne concordance entre les valeurs théorique et réelle, à la fois de $\left(\mathrm{H}_{1}+h\right)$ et du moment de flexion.

Nous entreprendrons, l'examen définitif de ces résultats dans les conclusions présentées à la fin de notre étude.

Les pertes de charge de l'écoulement, suivant la face du déversoir, ont été négligées, car elles n'intervienment pratiquement pas dans le calcul du moment de flexion. En effet, l'introduction d'un coefficient tenant compte de ces pertes de charge aurait pour seul effet de réduire la valeur effective de $\mathrm{H}_{0}$; l'équation (28) nous montre que, pour des valeurs données de $b$ et de $Q$, celle de $a^{2} H_{0}$ reste constante, quelle que soit la valeur admise pour $\mathrm{H}_{0}$. $\mathrm{Or}$, le moment de flexion est égal à :

$$
\mathrm{M}=\mathrm{M}^{\prime} \gamma a^{2} \mathrm{H}_{0}
$$

dans laquelle seule la valeur de $M^{\prime}$ varie lorsqu'on fait varier $\mathbf{H}_{0}$. La figure montre que $\mathrm{M}^{\prime} \cong a$ (environ), de sorte que $\mathrm{M} \cong a$ (environ). Puisque la valeur de $a^{2} \mathrm{H}_{0}$ reste constante, une réduction de $5 \%$ de la valeur de $\mathbf{H}_{0}$ correspondra à une augmentation de 2,5\%, seulement, de celle de $a$, et par suite de celle de M. Puisque la perte de charge est généralement inférieure à $5 \%$ (sauf pour des déversoirs de très grande hautcur), la valeur de $M$ ne varierait que de très peu (1 à $2 \%$ environ), si l'on tenait compte des pertes de charge.

\section{Présence de rejaillissements aux faibles débits.}

Dans tous les cas précédents, les débits étaient suffisamment importants pour que le passage de l'écoulement incliné à un écoulement horizontal puisse se faire progressivement, sans autre phénomène de rejaillissement que la formation de «panaches»sur les parois latérales.

Par contre, aux taibles débits, lorsque l'épaisseur du jet, $a$, est très faible, et que, par conséquent, la masse d'eau au repos s'accumulant dans la galerie est également peu importante, le jet retombe directement sur le radier, en donnant lieu à des rejaillissements importants, à de la turbulence, et en attaquant le béton du radier. Puisque de telles conditions défavorables ne peuvent, évidemment, être tolérées dans la pratique, des essais ont été entrepris afin de déterminer la valeur critique du débit au-dessous de laquelle de tels rejaillissements pourraient se produire.

Un critère numérique convenable paraît être le rapport entre l'épaisseur $a$ du jet, et la profondeur $\mathrm{H}_{1}+h$, de la masse d'eau au repos, s'accumulant derrière le jet, et présentant un 
«coussin» à l'écoulement, de manière à «guider» progressivement le changement de direction voulu du courant. En effet, les essais effectués avec des profondeurs de passe de $11 / 4,2$, et 3 pouces $(31,75,50,8$ et $76,2 \mathrm{~mm})$ ont montré que la valeur de ce rapport conditionnait, dans une grande mesure, l'existence des rejaillissements.

Les résultats ont été très simples et directs, et il serait inutile de les préciser davantage ici. Ils ont permis de conclure qu'une valeur critique de $\left(\mathrm{H}_{1}+h\right) / a$ se situe au voisinage de 8-10; puisque $a$ décroît plus rapidement que $\left(\mathrm{H}_{1}+h\right)$ lorsque le débit diminue, la valeur du rapport

$$
\left(\mathrm{H}_{2}+h\right) / a
$$

augmente lorsque le débit diminue. La valeur critique indiquée est donc une valeur minimale; dès que celle-ci est dépassée, il se produit des rejaillissements. Lorsque $\left(\mathrm{H}_{1}+h\right)>d$, et lorsque le volume entier de la galerie est occupé par la masse d'eau au repos, on peut tolérer une valeur un peu plus élevée du rapport $\left(\mathrm{H}_{1}+h\right) / a$ que lorsque $\left(\mathrm{H}_{1}+h\right)<d$, de sorte que le jet doit franchir un espace libre. En résumé, pour qu'il n'y ait pas de rejaillissement :

pour $\left(\mathrm{H}_{1}+h\right)<d,\left(\mathrm{H}_{1}+h\right) / a>8$, pour $\left(\mathrm{H}_{1}+h\right)>d,\left(\mathrm{H}_{1}+h\right) / a \ngtr 10$;

la valeur calculée de $\left(\mathrm{H}_{1}+h\right)$ intervenant dans tous les cas.

\section{Résultats obtenus avec la galerie ouverte.}

Lors de chaque essai, la mesure des débits a été effectuce par la méthode volumétrique; la hauteur piézométrique à l'intérieur de la galerie a également été mesurée, ce qui a permis de déterminer la valeur du débit $Q_{2}$, et ensuite, par soustraction, le débit $Q_{1}$ du déversoir (le partage de l'écoulement, à l'amont du déversoir, rend la détermination de $Q_{1}$, à partir de la hauteur sur le déversoir, assez aléatoire). La hauteur, $h$, du point $H$ (fig. $7 a$ ) au-dessus du fond de la passe, a également été mesurée, et les valeurs ainsi obtenues, portées sur l'abaque de la figure 4 . Cette hauteur a été prise comme base (de nouveau assez arbitrairement) pour la mesure de $\mathrm{H}_{0}$, afin de permettre la détermination de la profondeur $a$ à partir de l'équation (28). Le débit libre $Q_{0}$ se déduit évidemment à partir de l'équation classique :

$$
\mathrm{Q}_{0}=b d \sqrt{2 g \mathrm{H}_{0}}
$$

$\mathrm{H}_{0}$ étant mesurée vers le haut, à partir du point E. Mais puisque $\mathrm{E}$ n'est pas nécessairement au même niveau que $H$, la valeur de $Q_{0}$ donnée par l'équation (29) sera généralement différente de celle fournie par l'équation (27).

L'examen de la figure 8 montre que les valeurs expérimentales des rapports des débits s'accordent remarquablement bien avec celles données par les courbes théoriques, ceci surtout dans le cas du rapport $\left(Q_{1}+Q_{2}\right) / Q_{0} ;$ La valeur minimale indiquée par la théorie se trouve ainsi bien confirmée par l'expérience.

Nous devrions, en effet, pouvoir nous attendre à une meilleure concordance entre la théorie et l'expérience, dans le cas où la vanne de la galerie est fermée, ceci pour deux raisons : d'une part, la hauteur à laquelle se situe le filet d'écoulement supérieur varie moins, de sorte que la vitesse tend plus neltement à devenir constante, et, d'autre part, puisque la vitesse, ainsi que la première dérivée de celle-ci, sont continues, à travers le filet de séparation EB, la valeur des contraintes de cisaillement suivant cette ligne sont beaucoup moins élevées que celles des contraintes suivant la ligne EOF lorsque la vanne est fermée.

La figure 4 montre que l'unique valeur de $h / d$ calculée à partir de la théorie se situe nettement (d'environ $10 \%$ ) au-dessous de la ligne matérialisée par les points expérimentaux. Cet écart paraît indiquer que la gravité (dont l'influence a été négligée dans l'analyse) intervient de manière que le courant inférieur soulève l'ensemble du courant supérieur, sans toutefois entraîner de variation importante des rapports des débits indiqués par la théorie. Cette notion pose une intéressante question de principe, mais elle ne sera pas approfondie dans la présente étude, étant donné l'intérêt pratique limité d'un tel régime d'écoulement.

\section{5. - CONCLUSIONS}

1. Lorsque la vanne de la galerie est fermée, la théorie (voir fig. 3-6) s'accorde bien avec l'expérience, pour $d / \mathrm{H}_{0} \leqslant 0,2 ;$ au-dessus de cette limite, l'influence localisée de la gravité rend lanalyse moins précise. Même lorsque

$$
d / \mathrm{H}_{0} \leqslant 0,2 \text {, }
$$

il se trouve, à l'aval de la ligne LOH, une concentration de pression que ne laisse guère entrevoir la théorie. A mesure que la valeur de $a / d$ décroît, ce «bulbe» de pression se déplace vers l'amont et lorsque $a / d=0,25$, il se situe dans le même alignement que LOH. La valeur du mo- 
ment de flexion suivant $\mathrm{LOH}$ ne dépasse jamais la valeur théorique de plus de $10 \%$, mais pour $a / d>0,4$, lorsque le «bulbe» de pression est nettement à l'aval de $\mathrm{LOH}$, il faut tenir compte de l'existence d'un moment de flexion suivant RS (fig. 9), dont la valeur est égale à environ $75 \%$ de celle du moment suivant LOH.

2. Lorsque la vanne de la galerie est ouverte, les rapports de débit sont tels que l'indique la théorie (fig. 8), mais la surface libre se situe à une cote un peu plus ćlevée. Pour $a / d<0,23$, $2 \alpha=45^{\circ}$, la valeur du débit global s'écoulant, à la fois, par-dessus le déversoir et par la galerie, est inférieure à ce qu'elle serait si la totalité du débit passait par la galerie. Pour $2 \alpha=45^{\circ}$, la valeur critique $d u$ rapport $a / d$ est quelque peu inférieure à 0,23 . Il est difficile de calculer la répartition des pressions et des vitesses, mais la valeur du moment de flexion suivant la ligne LOH paraît atteindre à peu près le double de celle correspondant au cas de la vanne de galerie fermée.

3. L'influence de la résistance à l'écoulement sur les valeurs calculées du moment de flexion est peu sensible, puisque, pour une valeur donnée de $Q$, le produit $a^{2} \mathrm{H}_{0}$ reste constant même lorsque la valeur de $\mathrm{H}_{0}$ se trouve diminuée par la r'ésistance à l'écoulement. Comme dans le cas de l'écoulement autour des corps immergés, l'existence même de la couche limite ne paraît guère entraîner de modification sensible de la répartition des pressions.

4. On tient aisément compte de l'aération à l'aide de données telles que celles indiquées par Elavatorski [4]. Lorsque la valeur de a se trouve augnentée, par l'aération, d'un facteur $m(>1)$, le poids spécifique $\gamma$ est également réduit de ce même facteur $m$.

Nous avons :

$$
\mathrm{M}=\mathrm{M}^{\prime} \frac{1}{2} \rho v_{1}^{2} a^{2}=\mathrm{M}^{\prime} \gamma \mathrm{H}_{0} a^{2}
$$

avec $\mathrm{M}^{\prime} \cong a$ (environ) (fig. 3 ). Ceci nous donne $\mathrm{M} \cong \gamma a^{3}$ (environ), et en remplaçant, d'une part, $a$ par $m a$, et, d'autre part, $\gamma$ par $\gamma / m$, nous voyons que $M$ est augmentée du facteur $m^{2}$. De même, les valeurs de $F$ et de $\vec{y}$, se trouvent augmentées chacune du facteur $m$.

\section{6. - REMERCIEMENTS}

Les essais sur modèle effectués par le Ministère des Travaux de la Nouvelle-Zélande pour le projet d'aménagement hydroélectrique de Roxburgh, ont été dirigés par M. F. R. Askin, ingénieur en chef (Energie). C'est grrâce à l'autorisa- tion aimablement accordée par M. F. M. Hanson, «Commissioner of Works », que nous avons pu évoquer ces essais dans la présente étude; l'auteur l'en remercie.

\section{NOTRE FRONTISPICE}

(Cf. p. 700)

JOULE (1818-1889)

Contrairement à la pluphart des savants de son époque, Joule ne fréquenta aucune école d'enseignement supérieur; mais l'absence de diplômes ne l'empêcha point d'être reçu, en 1850, membre de la Royal Society à Londres, en 1871, dacteur ès lois de l'Université d'Edimbourg et en 1875 , docteur ès sciences physiques et mathématiques de l'Université de Leycle.

C"est qu'entre-temps James Prescott Jonle, né à Salford (G.-B.) le 24 décembre 1818 , avait amassé un solide bagage scientifique daus la fréquentation de maitres particuliers, dont l'un fut le physicien Dalton avec qui il commença l'étude du magnétisme. L'ceuvre de Joule fut dominée par l'électrothermodynamique. C'est en 1842 qu'il formula les lois qui portent son nom et qui concernent la quantité de chaleur engendrée par un courant clectricue dans un conducteur métallique, phónomène connu depuis lors sous le nom d' " effet Joule ". Et en 1843, son mémoire sur l'équivalent mécanique de la chalcur, dont le premier il donna la valear numérique, eut un grand retentissement; c'est en hommage à ces travaux qu'en 1882 William von Siemens fit adopter le nom du savant anglais pour désigner l'unité d'énergie, le "joule " tevant valoir un watt-seconde. Les effets calorifiques du mowvement des fluides furent aussi l'objet de son attention. Les nombreux mémoires qu'il publia furent réunis et édités ì Londres en 1884-1887 sons le titre de Scintific Papers.

Joulc mourut à Sale, près de Manchester, le 11 octobre 1889

\section{JOULE (1818-1889)}

Unlike most of the scientists of his day, Jonle received no university education but his lack of qualifications did not prevent his admission to the Royal Soriety in London in 1850 nor to the degrecs of Doctor of Laws of Edinburgh Untiversity in 1871 and Doctor of Mathematics and Physics of Leyden University in 1875

The fact is that James Prescott Joule, born in Salford on the 24th December, 1818, had in the neantime acquired a sound store of scientific knowledge from his association with various masters, one of whom was Dalton, who guided his first efforts in the study of magnetism.

oule's work was dominated by electro-thermo-dynamics. It was in 1842 that he formulated his eponymous laws on the amount of heat produced by an electric current in a metallic conductor the phenomenon has beell called the "Joule effect" ever since. In 1843 his pafer on the mechanical equivalent of heat, zohich he aras the frrst to determine numerically, bust upon the scien titic world, and it alas in homage to this zoork that William von Siemens zen acceptance of the term "joule" in 1882 to describe the unit of energy equivalent to one watt per second. He also studied the calorific effects of fluid motion

His mimerons papers were collected and published in London bctwen 1884 and 1887 tuder the title of Scientific Papers. Joule died in Sale, near Manchester, on the 11th October, 1889. 